Prepared for the U.S. Department of Energy

under Contract DE-AC05-76RL01830

\title{
Soil Water Balance and Recharge Monitoring at the Hanford Site - FY 2010 Status Report
}

MJ Fayer

DL Saunders
RS Herrington

D Felmy

October 2010

\section{Pacific Northwest}

NATIONAL LABORATORY

Proudly Operated by Battelle Since 1965 


\title{
DISCLAIMER
}

This report was prepared as an account of work sponsored by an agency of the United States Government. Neither the United States Government nor any agency thereof, nor Battelle Memorial Institute, nor any of their employees, makes any warranty, express or implied, or assumes any legal liability or responsibility for the accuracy, completeness, or usefulness of any information, apparatus, product, or process disclosed, or represents that its use would not infringe privately owned rights. Reference herein to any specific commercial product, process, or service by trade name, trademark, manufacturer, or otherwise does not necessarily constitute or imply its endorsement, recommendation, or favoring by the United States Government or any agency thereof, or Battelle Memorial Institute. The views and opinions of authors expressed herein do not necessarily state or reflect those of the United States Government or any agency thereof.

\author{
PACIFIC NORTHWEST NATIONAL LABORATORY \\ operated by \\ BATTELLE \\ for the \\ UNITED STATES DEPARTMENT OF ENERGY \\ under Contract DE-AC05-76RL01830
}

Printed in the United States of America

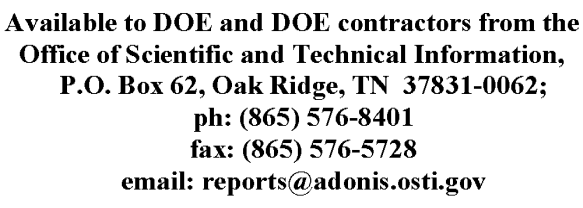

\footnotetext{
Available to the public from the National Technical Information Service, U.S. Department of Commerce, 5285 Port Royal Rd., Springfield, VA 22161 ph: (800) 553-6847 fax: $(703) 605-6900$ email: orders@ntis.fedworld.gov online ordering: http://www.ntis.gov/ordering.htm
}

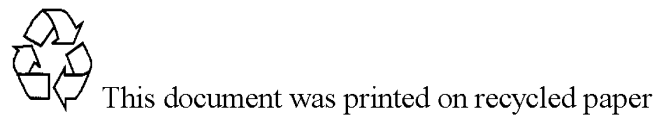




\title{
Soil Water Balance and Recharge Monitoring at the Hanford Site - FY 2010 Status Report
}

\author{
MJ Fayer \\ RS Herrington \\ DL Saunders \\ D Felmy
}

October 2010

Prepared for

the U.S. Department of Energy

under Contract DE-AC05-76RL01830

Pacific Northwest National Laboratory

Richland, Washington 99352 



\section{Summary}

This report summarizes the recharge data collected in FY 2010 at five locations on the Hanford Site in southeastern Washington State. From late fall to early spring of FY 2010, precipitation and temperature conditions did not present an opportunity for increased recharge. The recharge monitoring data confirmed these conditions, showing normal behavior in water content, matric head, and recharge rates. Also provided in this report is a strategy for recharge estimation for the next 5 years. 



\section{Acknowledgments}

We would like to acknowledge the support provided by the contractor, CH2M HILL Plateau Remediation Company. We are grateful to Steve Phillips (Applied Geotechnical Engineering and Construction, Inc.) for providing the drainage volumes from the Solid Waste Landfill Lysimeter. We wish to acknowledge Pacific Northwest National Laboratory staff Chris Strickland (Hydrology Group) and Ray Clayton (Environmental Assessment Group) for their help in collecting data from the field sites. We thank Cristian Iovin (Geosciences Group) for analyzing the drainage samples for chloride. Finally, we wish to acknowledge the significant contributions of Randy Kirkham (Hydrology Group) to the

conceptual design and construction of the Field Lysimeter Test Facility during 1986 and 1987. His initial prototype was built using soda cans and Styrofoam and proved to be a winning design. 



\section{Abbreviations and Acronyms}

$\begin{array}{ll}\text { CHPRC } & \text { CH2M HILL Plateau Remediation Company } \\ \mathrm{cm} & \text { centimeter(s) } \\ \text { DOE } & \text { U.S. Department of Energy } \\ \text { FLTF } & \text { Field Lysimeter Test Facility } \\ \text { HMS } & \text { Hanford Meteorological Station } \\ \mathrm{hr} & \text { hour(s) } \\ \mathrm{IDF} & \text { Integrated Disposal Facility } \\ \text { ILAW } & \text { immobilized low-activity waste } \\ \text { in. } & \text { inch(es) } \\ \mathrm{km} & \text { kilometer(s) } \\ \mathrm{m} & \text { meter(s) } \\ \mathrm{mm} & \text { millimeter(s) } \\ \text { P+I } & \text { precipitation plus irrigation } \\ \text { PNNL } & \text { Pacific Northwest National Laboratory } \\ \text { SWL } & \text { Solid Waste Landfill } \\ \text { WFM } & \text { water flux meter } \\ \text { yr } & \text { year(s) }\end{array}$





\section{Contents}

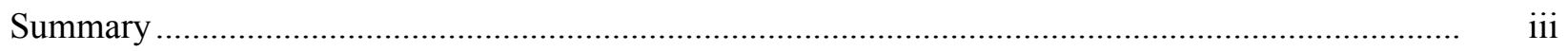

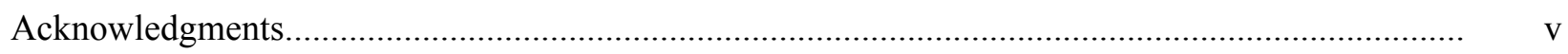

Abbreviations and Acronyms …............................................................................................ vii

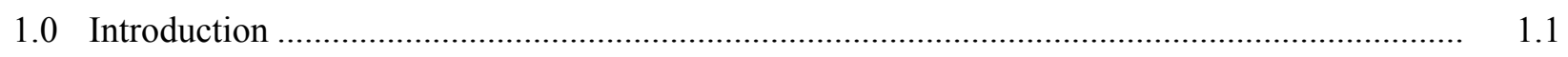

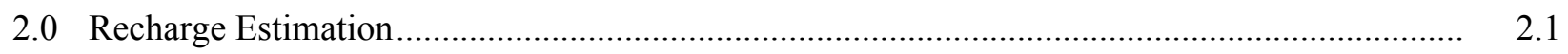

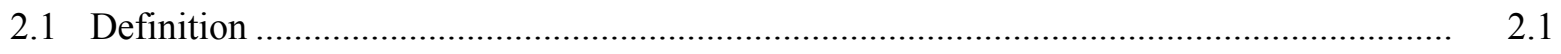

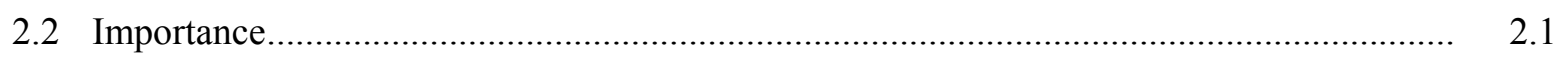

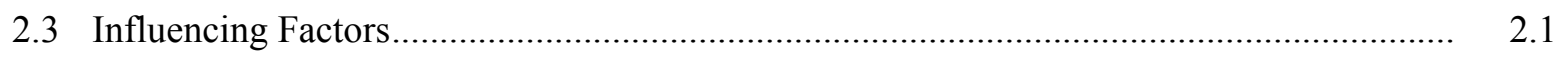

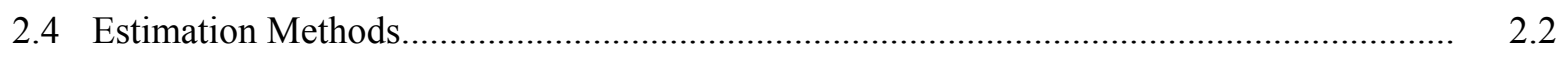

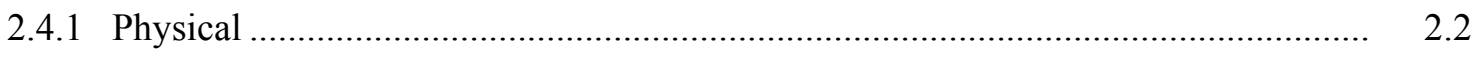

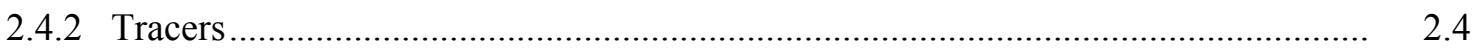

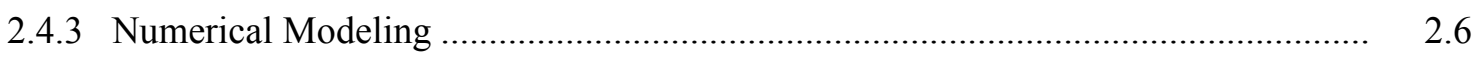

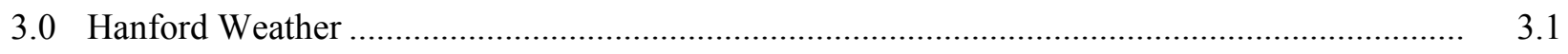

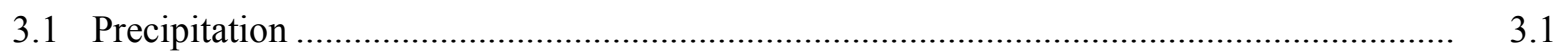

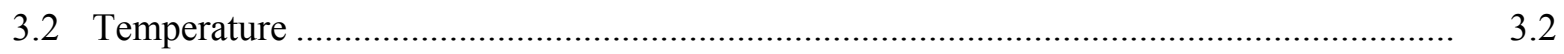

4.0 Recharge Sites and Monitoring Activities in FY 2010 ...................................................

4.1 Field Lysimeter Test Facility ................................................................................. 4.1

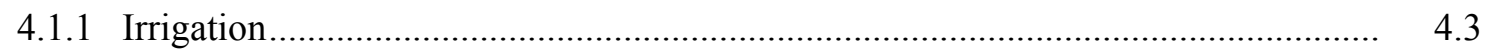

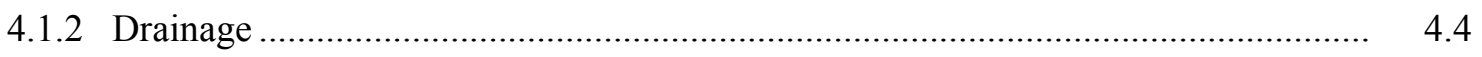

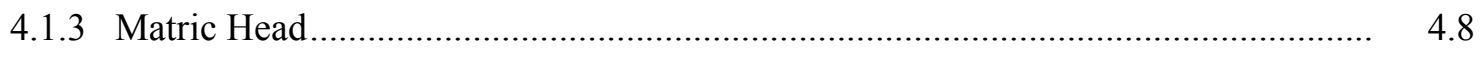

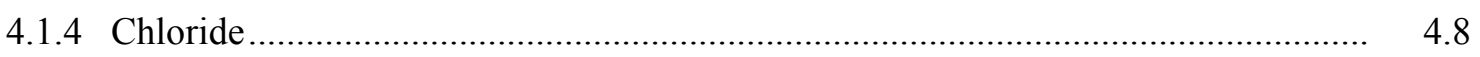

4.2 Field Lysimeter Test Facility Pit ................................................................................ 4.9

4.3 Integrated Disposal Facility Dune Site ...................................................................... 4.11

4.4 Solid Waste Landfill Lysimeter .............................................................................. 4.11

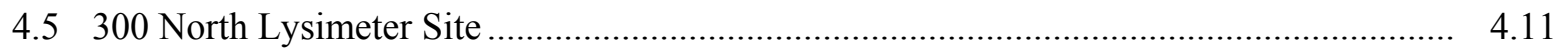

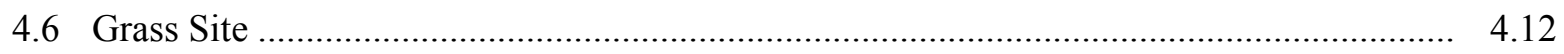

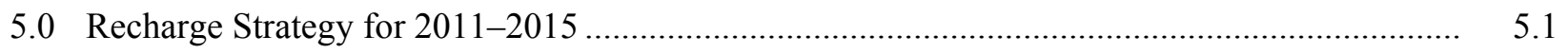

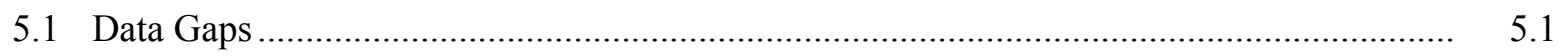

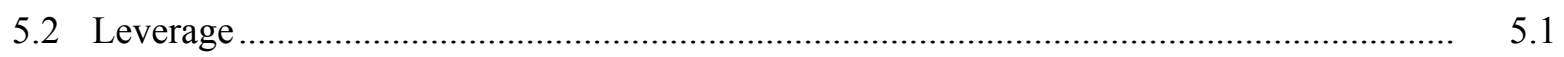

5.3 Recommendations for Existing Monitoring Sites ..................................................... 5.1

5.3.1 Field Lysimeter Test Facility ...................................................................... 5.1

5.3.2 Integrated Disposal Facility Dune Site........................................................... 5.4

5.3.3 Solid Waste Landfill Lysimeter ................................................................... 5.5

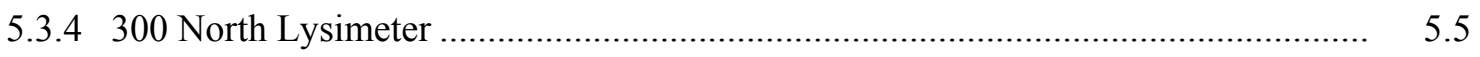

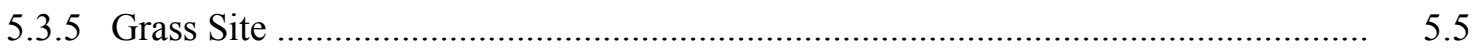

5.4 Modeling Calibration and Validation..................................................................... 5.5

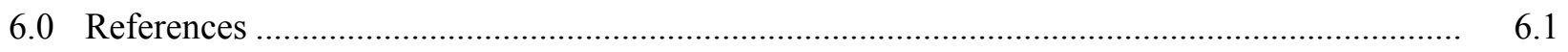




\section{Figures}

1.1 Locations of Recharge Monitoring Stations at the Hanford Site .......................................... 1.2

2.1 Plan View and Cross-Section View of 300 North Lysimeter Facility ..................................... 2.3

2.2 Installed Vadose Zone Water Flux Meter with Diversion Control .......................................... 2.4

4.1 Artist Rendering of the Field Lysimeter Test Facility at the Hanford Site ............................. 4.1

4.2 Field Lysimeter Test Facility Precipitation and Irrigation Target, Actual in 2010,

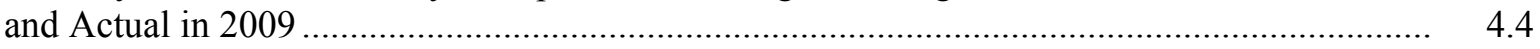

4.3 Cumulative Drainage from Field Lysimeter Test Facility Caissons D10, D12, and W4 .......... 4.4

4.4 Cumulative Drainage from Field Lysimeter Test Facility Caissons D6 and D8 ...................... 4.5

4.5 Cumulative Drainage from Field Lysimeter Test Facility Lysimeters D2 and D4 .................. 4.5

4.6 Cumulative Drainage from Lysimeters D3 and D13 ....................................................

4.7 Cumulative Drainage from Clear Tube Lysimeters C1, C2, C4, and C5 ............................... 4.6

4.8 Matric Heads in the Sand Dune Test at Depths of 100, 150, and $210 \mathrm{~cm}$............................... 4.8

4.9 Cumulative Drainage from Water Flux Meters at the Field Lysimeter Test Facility Pit Site

4.10 Cumulative Drainage from the Solid Waste Landfill Lysimeter ........................................... 4.11

4.11 Water Content Variations at Three Depths in the 300 North Lysimeter in 2010 .................... 4.12

4.12 Water Content at Two Depths at the Grass Site in 2010 .......................................................

\section{Tables}

1.1 Monitoring Sites, Activities, and Periods

3.1 Monthly Precipitation Measured at the Hanford Meteorological Station.

3.2 Average Monthly Air Temperature Measured at the Hanford Meteorological Station

4.1 Summary of Treatments and Applicable Dates at the Field Lysimeter Test Facility

4.2 Field Lysimeter Test Facility Treatment Descriptions

4.3 Summary of Treatments Results at the Field Lysimeter Test Facility...

4.4 Chloride Concentrations Measured in Field Lysimeter Test Facility Lysimeter Drainage Waters

4.5 FLTF Pit Treatments, Monitoring Periods, and Average Drainage Rates for a Subset of Data.

5.1 Ranking of Recharge Data Gaps

5.2 Recommendations for Field Lysimeter Test Facility Lysimeters 


\subsection{Introduction}

Recharge at the Hanford Site predominantly refers to the flux of water that begins as precipitation that infiltrates the soil surface, passes through the vadose zone, and enters the groundwater. Such recharge is important at the Hanford Site for its ability to affect subsurface contaminants. In particular, the water passing through the vadose zone can mobilize contaminants and transport them to the groundwater, where they can move relatively quickly toward and into the Columbia River.

Pacific Northwest National Laboratory (PNNL) collected data from several field sites in FY 2010 to characterize or estimate recharge rates for specific soil-plant-precipitation combinations. PNNL conducted this activity for CH2M HILL Plateau Remediation Company (CHPRC) in support of the U.S. Department of Energy (DOE).

Recharge is sensitive to weather conditions. Several years to a decade or more can pass before weather conditions occur that are conducive to recharge. Thus, monitoring records of 3,5, or even 10 years may be insufficient to characterize accurately the long-term recharge rate for soil and plant combinations. It is important to collect recharge data for as long as possible to increase the credibility of recharge estimates of future conditions. In addition, some of the data are collected for tests with wetter conditions (i.e., higher precipitation rates) to provide recharge estimates for possible climate change scenarios.

The scope of this report covers data collection activities performed in FY 2010 at the Field Lysimeter Test Facility (FLTF; 24 lysimeters), the Solid Waste Landfill (SWL; 1 lysimeter), the Integrated Disposal Facility (IDF) Dune Site, the 300 North Lysimeter (1 lysimeter), and the Grass Site (2 lysimeters). Figure 1.1 shows the locations of those and other recharge sites, and Table 1.1 shows the status of those sites. Because recharge rates depend on weather conditions, the report provides a short summary of weather conditions during FY 2010. Finally, because of the importance of recharge to environmental remediation and long-term performance of disposal facilities, this report provides recommendations for a strategy to guide recharge activities in FY 2011 through 2015.

Organizationally, the balance of this report is divided into five sections. Section 2 briefly defines recharge and describes its importance, influencing factors, and estimation techniques. Section 3 describes the weather conditions in 2010. Section 4 reviews the recharge data collected in 2010. Section 5 presents recommendations for a recharge strategy for the next 5 years. Sources cited in the text are listed in Section 6. 


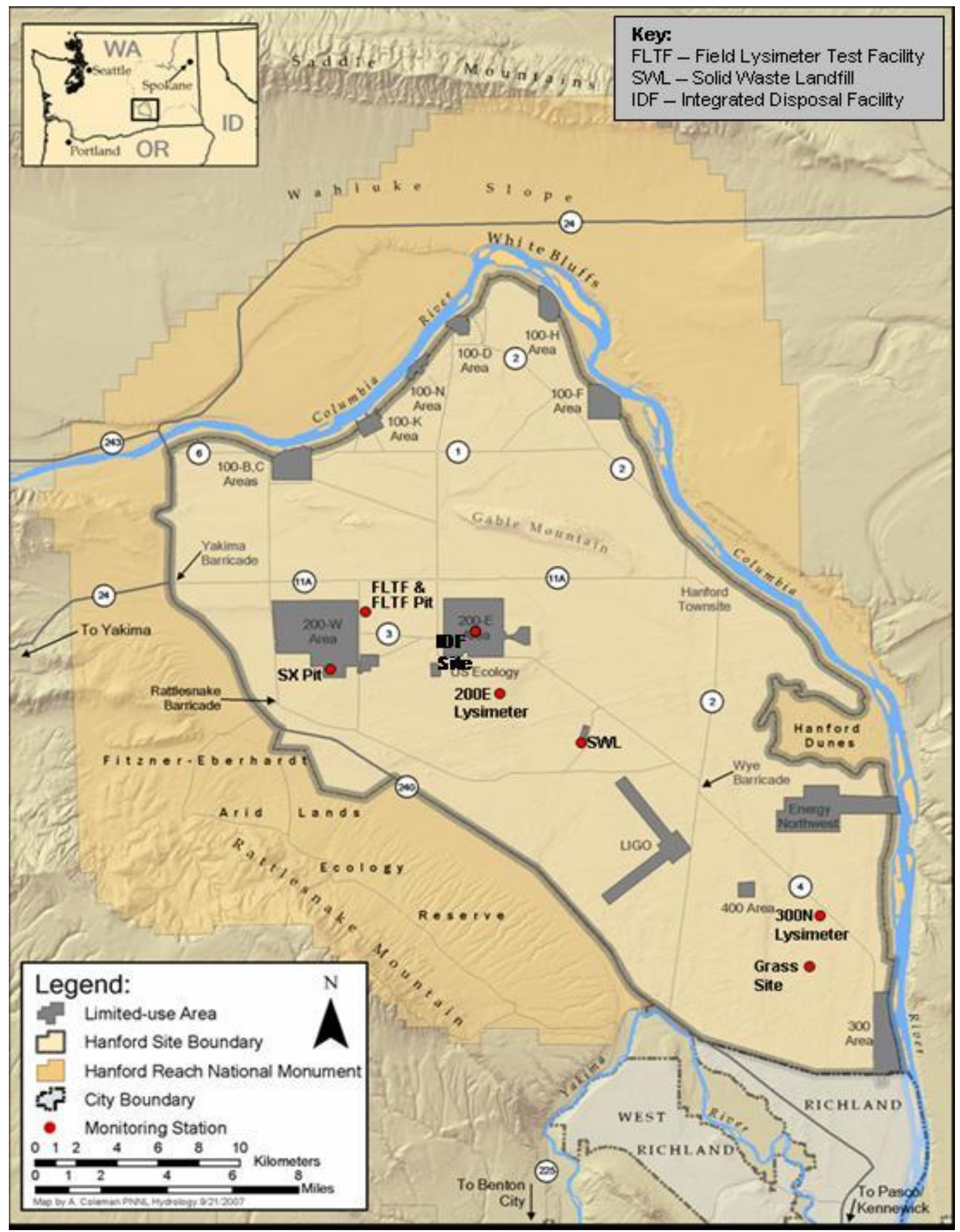

Figure 1.1. Locations of Recharge Monitoring Stations at the Hanford Site (after Rockhold et al. 2009) 
Table 1.1. Monitoring Sites, Activities, and Periods (after Rockhold et al. 2009)

\begin{tabular}{|c|c|c|}
\hline Monitoring Site $^{(a)}$ & Monitoring Activities & Monitoring Periods \\
\hline Grass Site & Water flux, water content & February 1,2005 , to present \\
\hline 300 North Lysimeter & $\begin{array}{l}\text { Water flux, water content, } \\
\text { matric potential }\end{array}$ & $\begin{array}{l}1981 \text { to December } 2006 \\
\text { (Wind damage outage) } \\
\text { February } 2007 \text { to present }\end{array}$ \\
\hline Solid Waste Landfill ${ }^{(b)}$ & Water flux, water content & December 2004 to present \\
\hline $\begin{array}{l}\text { Integrated Disposal } \\
\text { Facility (IDF) }\end{array}$ & $\begin{array}{l}\text { Environmental tracer methods, } \\
\text { water content }\end{array}$ & 2000 to present \\
\hline 200 East Lysimeter & Water content & 1991 to 2007 \\
\hline $\begin{array}{l}\text { Field Lysimeter Test } \\
\text { Facility (FLTF) }\end{array}$ & $\begin{array}{l}\text { Water flux, water content, } \\
\text { matric potential }\end{array}$ & 1987 to present \\
\hline $\begin{array}{l}\text { Field Lysimeter Test } \\
\text { Facility (FLTF) Pit }\end{array}$ & Water flux & 2001 to present \\
\hline Tank Farms & $\begin{array}{l}\text { B: Water flux, water content } \\
\text { SX: Water flux, water content } \\
\text { TX: Matric potential }\end{array}$ & $\begin{array}{l}\text { B: } 2001 \text { to } \sim 2003 \\
\text { SX: January } 2003 \text { to September } 2007 \\
\text { TX: October } 2002 \text { to September } 2007\end{array}$ \\
\hline
\end{tabular}

(a) Site names styled in bold font were still active at the end of FY 2010.

(b) Leachate data from the Solid Waste Landfill have been collected since 1996. 



\subsection{Recharge Estimation}

This section defines recharge and describes its importance, influencing factors, and estimation techniques. Much of the section is background material that was taken from a variety of sources, including Rockhold et al. (2009), Nichols et al. (2008), and Fayer and Keller (2007).

\subsection{Definition}

Recharge is generally defined as the flux of water that enters, or "recharges," the groundwater. There are potentially several sources of recharge, including precipitation, inflow from streams and rivers, and upwelling from deeper aquifers. At the Hanford Site, "recharge" most often refers to the flux of water transmitted across the water table from the vadose zone to the saturated zone. Direct measurement of recharge at the water table is usually impractical due to inaccessibility, especially at the Hanford Site where the water table is commonly located at depths of $80 \mathrm{~m}$ or more below ground surface. The effects of aquifer-influencing operations, such as artificial discharges or remediation pump-and-treat systems, would further complicate efforts at making a direct measurement for a deep water table. Instead, measurements and analyses in the unsaturated zone at shallow depths are used to characterize deep drainage - that is, the water flux leaving the depth below which the processes of evaporation and transpiration can return water from the unsaturated soil to the atmosphere. This deep drainage, with sufficient time, will be manifest as the recharge flux. The time required will depend on the thickness and hydraulic properties of the vadose zone and the deep drainage rate itself. Changes in the deep drainage rate, such as would result from changes in surface vegetative conditions that increase or decrease the evapotranspiration rate, can take many years to be reflected in the recharge rate for a thick vadose zone in arid conditions such as at the Hanford Site and can be an important consideration in characterizing recharge as well (Nichols et al. 2008).

\subsection{Importance}

Recharge is the primary mechanism for transporting contaminants from the vadose zone to groundwater. Bacon and McGrail (2002) demonstrated this by showing the sensitivity of buried immobilized low-activity waste (ILAW) glass release and transport to different rates of recharge. Their evaluation of the release of technetium-99 from the ILAW glass for five recharge rates revealed that the technetium-99 flux beneath the ILAW disposal zone is more sensitive to the recharge rate than to any other parameter for recharge rates below $10 \mathrm{~mm} / \mathrm{yr}$. Recharge rates in this range are common for natural vegetation and soil conditions at the Hanford Site. Such a high sensitivity of waste disposal performance to recharge rate underscores the need to characterize this parameter as accurately as possible.

\subsection{Influencing Factors}

Important physical properties and processes that influence recharge include climate, soil hydraulic properties and stratigraphy, vegetative cover, land use, and topography. Climate determines the driving forces for recharge, namely the quantity of precipitation available for the land surface water balance, and the energy fluxes that determine the partitioning of precipitation into evaporation, transpiration, and recharge. Soil hydraulic properties and stratigraphy determine the rate at which water is transmitted through the vadose zone and hence its resident time for processes of evaporation and transpiration. 
Vegetative cover determines the strength of the transpiration portion of the land surface water balance. Land use will change other influencing factors by altering the surface soils and hence the hydraulic properties and soil stratigraphy of a site, and the vegetative cover and hence transpiration rates. Topography influences the portion of precipitation that is subject to overland flow, either "run on" or "runoff," for a given site. Knowledge of all of these influences is important to the estimation of recharge at a given location.

\subsection{Estimation Methods}

Recharge rates at the Hanford Site can range from near zero to more than $100 \mathrm{~mm} / \mathrm{yr}$ (Gee et al. 1992). Measuring a parameter that varies over such a large range requires use of complementary methods. An excellent overview of recharge estimation techniques is provided in Scanlon et al. (2002). The methods in use at the Hanford Site include physical techniques (water balance, lysimetry), tracer techniques (chloride, isotopes), and numerical techniques (computer simulation). These and other methods are discussed at length in the January-February 1994 issue of the Soil Science Society of American Journal, which contains a series of papers that were presented at a symposium titled "Recharge in Arid and Semiarid Regions." A brief overview of each technique in use at the Hanford Site is provided here for reference purposes.

\subsubsection{Physical}

Physical methods attempt to calculate recharge as a residual after other terms (precipitation, evaporation, transpiration, runoff, storage) are measured in the land surface water budget (water balance technique). Physical methods also directly measure recharge using an apparatus (lysimeter, water flux meters).

\subsubsection{Water Balance}

Water balance methods rely on measurement of several terms in the land surface water balance equation to derive recharge as a residual:

$$
D=P-E-T+\Delta R-\Delta S
$$

where $D$ is drainage (taken to represent recharge) calculated as total precipitation $(P)$ less water returned to the atmosphere through evaporation $(E)$ and transpiration $(T)$, plus net runoff $(\Delta R$, which is run on minus runoff) from the control surface, less the net change in storage of water in the soil zone to the depth that evapotranspiration processes affect $(\Delta S)$. Evapotranspiration $(E T)$ is the combination of the two distinctly different processes of evaporation and transpiration. Precipitation is easily and directly measured. Runoff is often not a parameter of importance for the soils of concern at the Hanford Site, except perhaps along the western edge of the site near Rattlesnake Mountain. Soil moisture must be measured over the depth range that is affected by evapotranspiration and at frequent time intervals to complete the calculation of recharge (drainage) as a residual. 


\subsubsection{Lysimetry}

A lysimeter is an in situ recharge measurement system that can be used to collect water that has flowed through and below the reach of the evaporation process and plant roots to become deep drainage and, eventually, recharge. The objective of lysimetry is to collect both performance data and model testing data for specific combinations of soil, vegetation, and precipitation. Lysimetry is one of only two methods available (the other being drainage flux meters) to directly measure deep drainage and thereby recharge. A lysimeter's primary strength is that it can provide a control volume in which a number of water balance components can be integrated and measured directly. This control volume provides the data necessary to calibrate numerical models that can be used to predict recharge. Figure 2.1 shows one type of lysimeter, located in the 300 North Area of the Hanford Site.
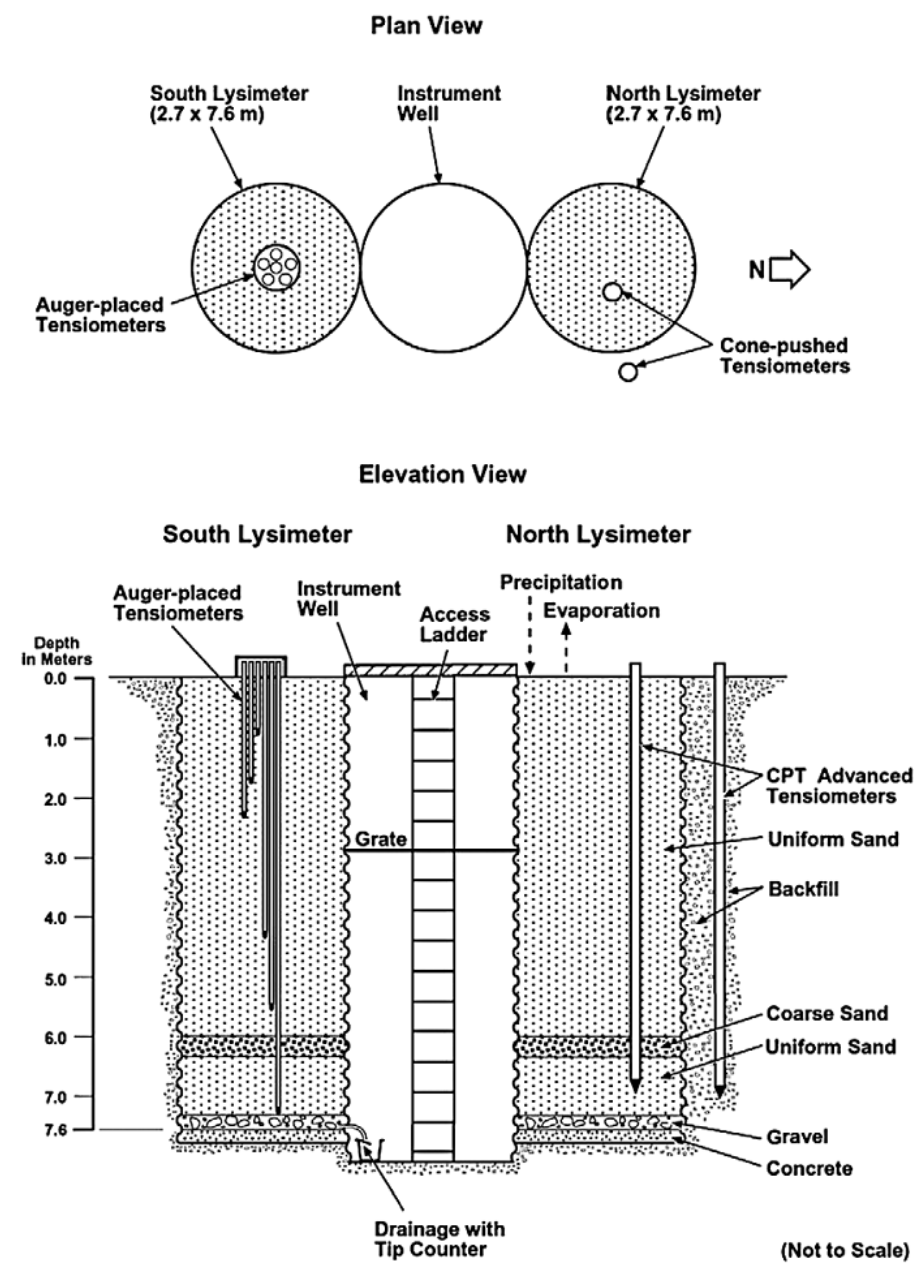

Figure 2.1. Plan View and Cross-Section View of 300 North Lysimeter Facility (after Fayer and Keller 2007)

Although lysimeters provide a direct measure of recharge, they have some disadvantages. Lysimeters are usually fixed in space, limiting their ability to quantify the effects of spatial variability. The soil filling the lysimeter may not represent the natural stratification or layering that may be present. The length of a lysimeter record is usually much shorter than time periods of interest, although the longer the lysimeter is operated, the more this drawback is alleviated. The lysimeter walls and base alter the natural 
gradients of temperature, air flow, and vapor flow that could be of importance in measuring low recharge rates (less than $1 \mathrm{~mm} / \mathrm{yr}$ ). Lysimeter walls restrict lateral root growth and artificially promote downward growth. When an irrigation treatment is used, lysimeter tests are subject to an "oasis effect," a scale effect in which heat from unirrigated surroundings increases the evapotranspiration rate above what it would have been if the entire area surrounding the lysimeter had been irrigated. Finally, it is critical to verify that no leaks of drainage water occur in the lysimeter before the data collected are used.

Lysimeters have long been used at the Hanford Site for several purposes (Hsieh et al. 1973; Gee and Jones 1985; Freeman and Gee 1989; Wittreich and Wilson 1991; Gee et al. 1993; Ward et al. 1997).

Lysimeters used to provide data reported in this compendium include containers that isolate the soil from its surroundings and field-scale pads that collect drainage but do not isolate the soil.

\subsubsection{Water Flux Meters}

The function and design of a vadose zone water flux meter (WFM) for direct, in situ measurement of recharge is described in Gee et al. $(2002,2003)$. Figure 2.2 shows that the design concentrates flow into a narrow sensing region filled with a fiberglass wick. The wick applies suction, proportional to its length, and passively drains the meter. Such a meter can be installed in an augured borehole at almost any depth below the root zone. Water flux through the meter is measured with a self-calibrating tipping bucket.

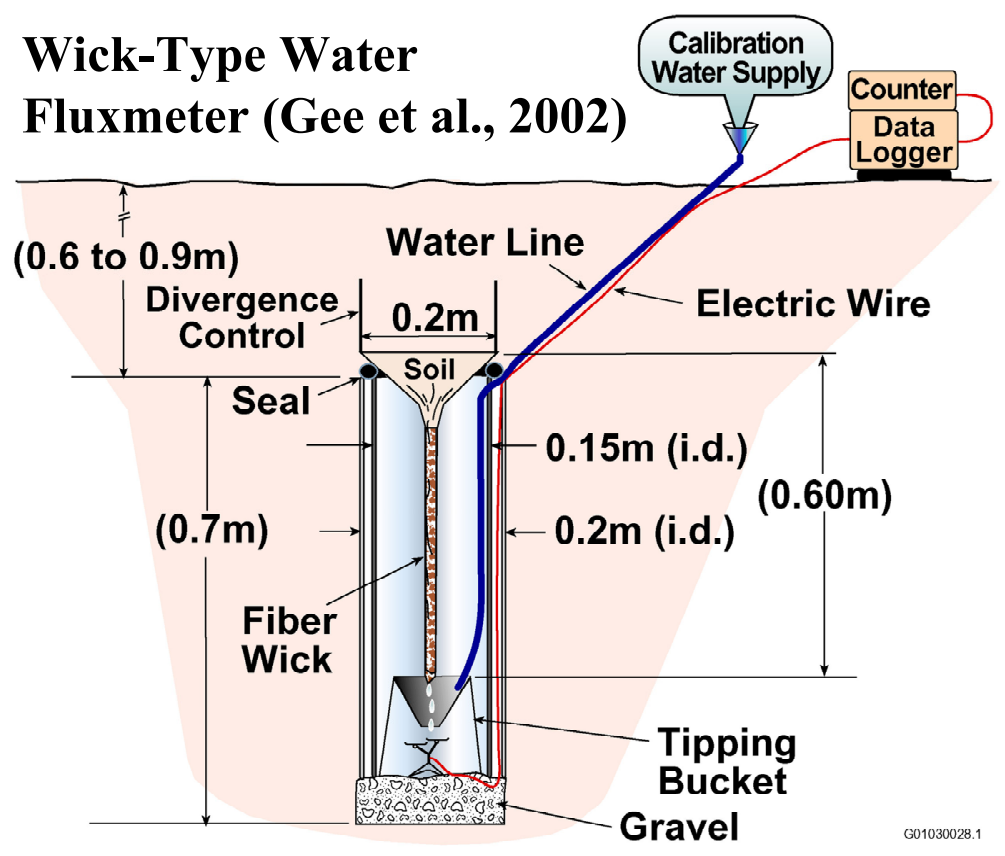

Figure 2.2. Installed Vadose Zone Water Flux Meter with Diversion Control (Gee et al. 2002)

\subsubsection{Tracers}

Tracer methods estimate past recharge by measuring the vertical distribution of a tracer in soil and sediments of the vadose zone. Several tracers are available that enable estimates of recharge rates: the tracers used at the Hanford Site have included chloride and chlorine-36 (Fayer et al. 1999; Fayer and Szecsody 2004) and the stable isotopes deuterium and oxygen-18 (DePaolo et al. 2004; Fayer and Szecsody 2004; Singleton et al. 2006). 


\subsubsection{Chloride and Chloride-36}

Chloride originates from seawater, is deposited naturally, and can provide recharge estimates spanning hundreds to thousands of years. Below the zone of evapotranspiration, the drainage flux, $q_{r}$, can be approximated as

$$
q_{r}=\frac{q_{C l}}{C_{C l-S w}} P
$$

where $q_{C l}$ is the chloride deposition rate $\left(\mathrm{mg} / \mathrm{m}^{2} / \mathrm{yr}\right)$ and $C_{C l-S w}$ is the concentration of chloride in soil water. The term $\left(q_{C l} \mathrm{P}\right)$ can be replaced with the term $C_{C l-P}$, which is equivalent to the concentration of chloride in precipitation water, including all chloride deposited in a dry state.

In contrast to chloride, the isotope chlorine-36 originates from two sources: cosmic irradiation of atmospheric chloride and surface and atmospheric nuclear weapons testing. The quantities of chlorine-36 created through nuclear weapons testing far exceed natural production rates from cosmic irradiation and therefore furnish a distinctive marker in the subsurface environment, particularly for arid regions with low recharge rates where this "bomb pulse" is still in transit through the vadose zone. Chlorine-36 data are used to estimate the average recharge rate over the last 50 years for such environments.

Both chloride and chlorine-36 are conservative, nonvolatile, and almost completely retained in the soil when water evaporates or is transpired by plants (Phillips 1994). Some chloride is subject to plant uptake; examples of this are shown in Rickard and Vaughn (1988) and in Sheppard et al. (1998). Over hundreds to thousands of years, plant cycling is expected to have a minimal impact on the evolution of the chloride distribution in the soil profile beneath plants. Recharge rates determined using chloride as a tracer reflect conditions that existed hundreds to thousands of years ago and are sometimes called paleorecharge or paleofluxes. When such paleofluxes are used to represent current or future conditions, the assumption is that the climate, soil, and vegetation conditions remain similar. In contrast, bomb-pulse chlorine-36 has been present in the environment for only about 50 years.

In soils with high $\mathrm{pH}$ and high adsorption of other anions, anion exclusion can result in faster movement of chloride. Previous studies strongly suggest a relationship between soil surface area, which is determined primarily by clay content, and anion exclusion; see, for example, Thomas and Swoboda (1970). Most of the sandy soil found at the Hanford Site has a relatively low percentage of clay, so the effects of anion exclusion in this soil would be relatively minor. Two other issues that affect chloridebased estimates of recharge are mineral dissolution and the chloride dilution that is part of the measurement technique. Both issues can be significant when recharge rates exceed a few millimeters per year (Tyler et al. 1999).

Phillips (1994) suggested that systematic uncertainties in estimated chloride deposition rates can be as great as $20 \%$ if the chloride mass balance technique is extended to estimate recharge rates prior to the Holocene epoch (approximately 10,000 years ago). Scanlon (2000) suggested the uncertainty was as high as $38 \%$. Because the Hanford Site was flooded by glacial melt water about 13,000 years ago, the interpretation is not extended beyond that time. Therefore, the uncertainty in chloride deposition rates at the Hanford Site is expected to be less than $38 \%$.

There is some uncertainty about the local influence that Hanford Site operations may have had on the time-dependent concentrations of both chloride and chlorine-36 deposited at the site (Fayer et al. 1999). 
Murphy et al. (1991) examined the issue relative to chlorine-36 and concluded there was no nearby source that would contribute additional chlorine- 36 to the sediment above and beyond the general atmospheric fallout.

\subsubsection{Deuterium and Oxygen-18}

Deuterium and oxygen-18 are naturally occurring inert isotopes of hydrogen and oxygen, respectively. Their concentration increases as the lighter components evaporate disproportionately. The increased concentration can be used to delineate seasonal variations in water flux, identify the depth of evaporative enrichment, and roughly estimate recharge.

The recharge rate is determined largely by the magnitude of transpiration and evaporation relative to precipitation and overland flow that has infiltrated the soil. Because water consists of several isotopes of hydrogen and oxygen, each with slightly different atomic weights, evaporation tends to remove the lighter isotopes preferentially. The net result is that the residual water contains a higher proportion of the heavier isotopes. There is a progressive decrease in the proportion of heavy stable isotopes with soil depth because evaporation decreases with depth and because of mixing with infiltrating water. At some depth, the isotopic profile becomes somewhat uniform; this depth represents the vertical extent of significant water vapor flux. The amount of enrichment (relative to the isotopic signature in precipitation) is indicative of the recharge rate. Murphy et al. (1991) described how deuterium and oxygen-18 could be used to understand recharge rates at the Hanford Site.

\subsubsection{Numerical Modeling}

Numerical modeling of unsaturated flow in the vadose zone can be used to estimate recharge rates. This method is ideal for situations and locations, or for scenarios, for which there are few to no data. This method introduces the highest level of uncertainty (of all the methods), which is why it is usually reserved for situations in which there are little or no data or to leverage limited short-term data to estimate longterm recharge.

Simulations of recharge at the Hanford Site have been successful at highlighting the important factors that affect recharge and predicting recharge rates for specific cases. Modeling is the primary tool for forecasting recharge rates for future climate and land-use scenarios. The simulations also allow the results of the lysimetry and tracer methods to be merged on a consistent basis.

Historically, the one-dimensional UNSAT-H computer code (Fayer 2000) has been used for estimating recharge at the Hanford Site. The multi-dimensional Subsurface Transport Over Multiple Phases (STOMP) simulator also has capabilities for estimating recharge based on site-specific soil, vegetation, and weather conditions (White and Oostrom 2006; Ward et al. 2005; Ward 2007). 


\subsection{Hanford Weather}

The DOE has operated the Hanford Meteorological Station (HMS) at the Hanford Site since the mid1940s (Hoitink et al. 2005). The HMS is located just outside the northeastern corner of the 200 West Area. Weather data collected include precipitation (rain and snow), air temperature, humidity, and wind speed. Measurements are recorded hourly and can be obtained via the Internet at http://hms.pnl.gov. The two parameters of most interest to recharge estimation are precipitation and air temperature, summarized below.

\subsection{Precipitation}

Table 3.1 shows that precipitation varied seasonally during FY 2010 compared to average monthly values for the period 1946 through 2009. During the winter months, which are the most likely for recharge conditions to occur because of low evaporation and transpiration, precipitation was at or below average values. During the months of May, June, and September, precipitation was much higher than average, but recharge was less likely to occur because of high evaporation and transpiration. Because of the high precipitation during those months, FY 2010 had total precipitation that was $1.91 \mathrm{in}$. in excess of the long-term average amount of 6.76 in. Years like this show that higher-than-normal annual precipitation is not a sufficient condition for increased recharge.

Table 3.1. Monthly Precipitation Measured at the Hanford Meteorological Station. All values were within the range of historical measurements at the HMS; negative variances are highlighted in red text.

\begin{tabular}{lccc}
\hline \multicolumn{1}{c}{ Month } & $\begin{array}{c}\text { Precipitation } \\
\text { (in.) }\end{array}$ & $\begin{array}{c}\text { Average Precipitation } \\
\text { 1946-2009 } \\
\text { (in.) }\end{array}$ & $\begin{array}{c}\text { FY 2010 Variance } \\
\text { Relative to } \\
\text { 1946-2009 Average (in.) }\end{array}$ \\
\hline October 2009 & 0.78 & 0.53 & 0.25 \\
November 2009 & 0.56 & 0.87 & -0.31 \\
December 2009 & 0.71 & 1.03 & -0.32 \\
January 2010 & 1.24 & 0.95 & 0.29 \\
February 2010 & 0.56 & 0.63 & -0.07 \\
March 2010 & 0.20 & 0.50 & -0.30 \\
April 2010 & 0.59 & 0.47 & 0.12 \\
May 2010 & 1.33 & 0.51 & 0.82 \\
June 2010 & 1.15 & 0.53 & 0.62 \\
July 2010 & 0.46 & 0.20 & 0.26 \\
August 2010 & 0.13 & 0.24 & -0.11 \\
September 2010 & 0.95 & 0.30 & 0.65 \\
\hline Annual Total & 8.66 & 6.76 & 1.91 \\
\hline
\end{tabular}

Winters with significant snowfall have a greater chance of experiencing increased recharge. In FY 2010, precipitation in the form of snow occurred in only one month (December) and the amount was 
4.8 in. This annual total is much less than the annual average of 15.4 in. Thus, snowfall in FY 2010 was less likely than normal to influence recharge rates.

\subsection{Temperature}

Table 3.2 shows how average monthly air temperatures varied seasonally in FY 2010 relative to the long-term average values. Temperatures in October and December 2009 were much colder than normal. Temperatures from January through March were much higher than normal, which would enhance evaporation and reduce the potential for recharge. Overall, the average air temperature in FY 2010 was $52.0^{\circ} \mathrm{F}$, which was $1.4^{\circ} \mathrm{F}$ lower than the long-term average value of $53.5^{\circ} \mathrm{F}$.

Table 3.2. Average Monthly Air Temperature Measured at the Hanford Meteorological Station. All values were within the range of historical measurements at the HMS; negative variances are highlighted in red text.

\begin{tabular}{lccc}
\hline \multicolumn{1}{c}{ Month } & $\begin{array}{c}\text { FY 2010 Average } \\
\text { Monthly Air } \\
\text { Temperature }\left({ }^{\circ} \mathrm{F}\right)\end{array}$ & $\begin{array}{c}\text { Long-Term }(1945-2009) \\
\text { Average Monthly Air } \\
\text { Temperature }\left({ }^{\circ} \mathrm{F}\right)\end{array}$ & $\begin{array}{c}\text { Variance Between } \\
\text { FY 2010 Monthly } \\
\text { Temperature and } \\
\text { 1945-2009 Average } \\
\left({ }^{\circ} \mathrm{F}\right)\end{array}$ \\
\hline October 2009 & 50.2 & 53.0 & -2.8 \\
November 2009 & 41.0 & 40.1 & 0.9 \\
December 2009 & 24.6 & 32.1 & -7.5 \\
January 2010 & 38.0 & 31.1 & 6.9 \\
February 2010 & 42.0 & 37.7 & 4.3 \\
March 2010 & 46.9 & 45.4 & 1.5 \\
April 2010 & 53.2 & 52.9 & 0.3 \\
May 2010 & 57.9 & 61.9 & -4.0 \\
June 2010 & 66.9 & 69.4 & -2.5 \\
July 2010 & 76.6 & 76.7 & -0.1 \\
August 2010 & 74.6 & 75.1 & -0.5 \\
September 2010 & 65.8 & 66.2 & -0.4 \\
\hline Annual Average & 53.1 & 53.5 & -0.3 \\
\hline
\end{tabular}




\subsection{Recharge Sites and Monitoring Activities in FY 2010}

This section provides a brief description of each recharge monitoring site followed by a summary of the data collected in FY 2010 along with data from previous years to provide context. The site description material came from a variety of sources, including Rockhold et al. (2009), Nichols et al. (2008), and Fayer and Keller (2007).

\subsection{Field Lysimeter Test Facility}

The Field Lysimeter Test Facility (FLTF), which is about $0.5 \mathrm{~km}$ east of the HMS, began operations in November 1987 (Gee et al. 1989). The facility has a total of 24 lysimeters of three different designs: 14 3-m-deep by 2-m-diameter drainage lysimeters; 63 -m-deep by 0.3 -m-diameter small-tube lysimeters; and $41.5-\mathrm{m}$ by $1.5-\mathrm{m}$ by $1.7-\mathrm{m}$-deep weighing lysimeters. All but 3 of these are monitored for drainage. The 3 unmonitored lysimeters were used for a separate unrelated project; that project decommissioned those lysimeters in summer 2010.

Figure 4.1 shows the layout of the FLTF. Automated hourly measurements of mass are made on all 4 weighing lysimeters. Matric heads are measured manually in 7 lysimeters at various depths. Temperatures within the lysimeters are measured at more than 50 locations, but those data are not summarized here. Of the 21 lysimeters being monitored, 9 are regularly irrigated to increase the total water received (i.e., precipitation plus irrigation) to $480 \mathrm{~mm} / \mathrm{yr}$, which is approximately three times greater than the current long-term average ambient precipitation of $172 \mathrm{~mm} / \mathrm{yr}$. Table 4.1 summarizes the test treatments for the monitored lysimeters. A brief description of each test is provided in Table 4.2.

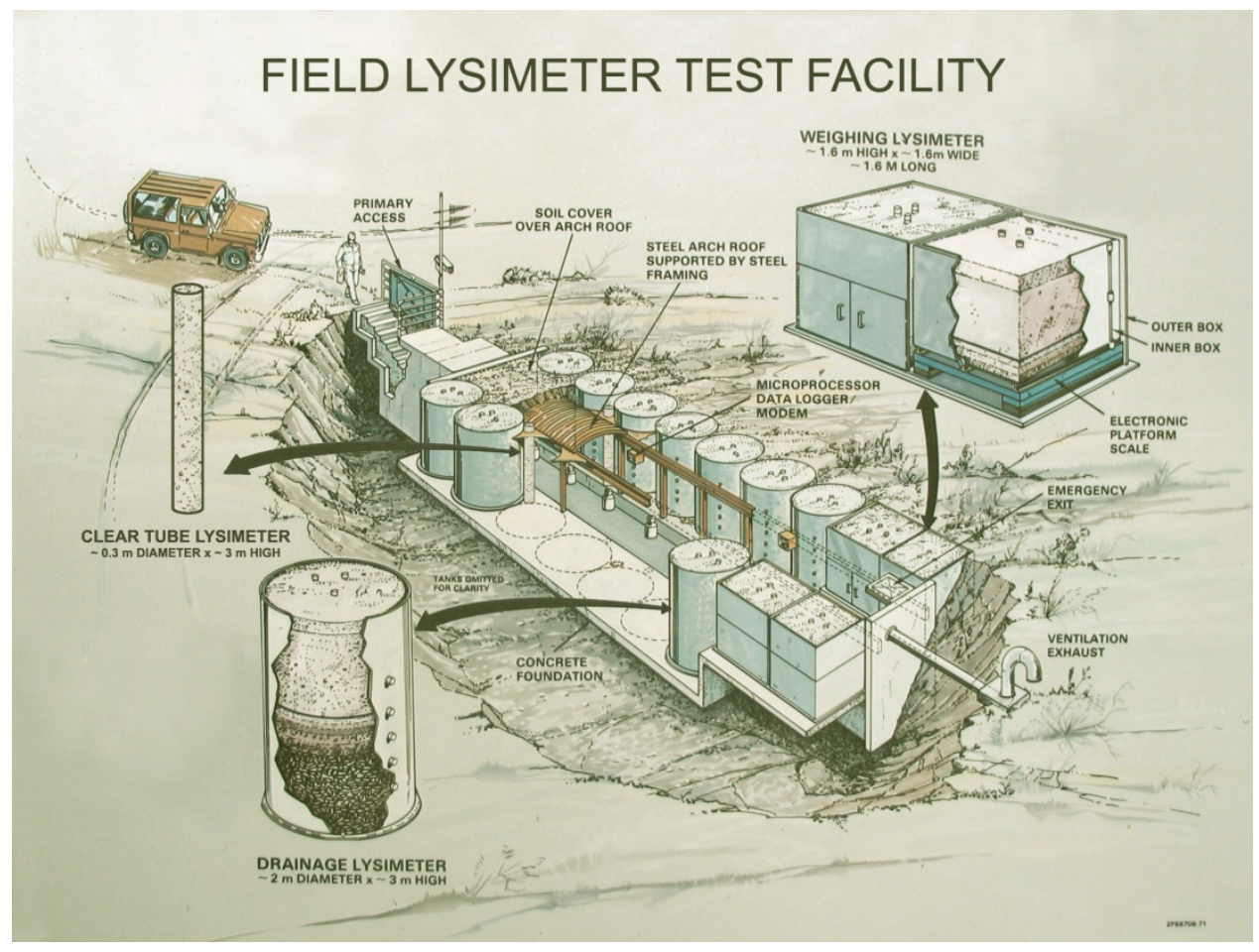

Figure 4.1. Artist Rendering of the Field Lysimeter Test Facility at the Hanford Site (Fayer and Gee 2006) 
Table 4.1. Summary of Treatments and Applicable Dates at the Field Lysimeter Test Facility (after Fayer and Szecsody 2004)

\begin{tabular}{|c|c|c|c|c|c|c|c|c|c|c|}
\hline \multirow[b]{2}{*}{ Test Description } & \multirow{2}{*}{$\begin{array}{l}\text { Treatment } \\
\text { ID No. }\end{array}$} & \multicolumn{3}{|c|}{ Precipitation } & \multicolumn{3}{|c|}{ Vegetation } & \multirow{2}{*}{$\begin{array}{l}\text { Lysimeter } \\
\text { ID }\end{array}$} & \multicolumn{2}{|c|}{ Monitoring Period } \\
\hline & & $1 x$ & $2 / 3 x$ & $3 x$ & NV & SRV & DRV & & Start & End \\
\hline \multirow[t]{16}{*}{ Hanford Barrier } & 1 & $\mathrm{X}$ & & & & & $X$ & D4 & 4 Nov 1987 & 22 Apr 1994 \\
\hline & & $\mathrm{X}$ & & & & & $\mathrm{X}$ & D7 & 4 Nov 1987 & 22 Apr 1994 \\
\hline & & $\mathrm{X}$ & & & & & $\mathrm{X}$ & W1 & 4 Nov 1987 & 15 Sep 2010 \\
\hline & & $\mathrm{X}$ & & & & & $X^{g}$ & $\mathrm{C} 3$ & 9 Nov 1988 & 15 Sep 2010 \\
\hline & 2 & $\mathrm{X}$ & & & $\mathrm{X}$ & & & D1 & 4 Nov 1987 & 15 Sep 2010 \\
\hline & & $\mathrm{X}$ & & & $\mathrm{X}$ & & & D8 & 4 Nov 1987 & 27 Feb 1998 \\
\hline & & $\mathrm{X}$ & & & $\mathrm{X}$ & & & W2 & 4 Nov 1987 & 31 Oct 1997 \\
\hline & 3 & & $\mathrm{X}$ & & & & $\mathrm{X}$ & D13 & 4 Nov 1987 & 27 Feb 1998 \\
\hline & & & $\mathrm{X}$ & & & & $\mathrm{X}$ & D14 & 4 Nov 1987 & 22 Apr 1994 \\
\hline & & & $\mathrm{X}$ & & & & $\mathrm{X}$ & W3 & 4 Nov 1987 & 15 Sep 2010 \\
\hline & & & $\mathrm{X}$ & & & & $\mathrm{X}$ & C6 & 9 Nov 1988 & 15 Sep 2010 \\
\hline & 4 & & $\mathrm{X}$ & & $\mathrm{X}$ & & & D10 & 4 Nov 1987 & 8 Apr 2002 \\
\hline & & & $\mathrm{X}$ & & $X$ & & & D12 & 4 Nov 1987 & 31 Oct 1997 \\
\hline & & & $\mathrm{X}$ & & $\mathrm{X}$ & & & W4 & 4 Nov 1987 & 31 Oct 1997 \\
\hline & 7 & & $\mathrm{X}^{\mathrm{a}}$ & & $\mathrm{X}$ & & & D9 & 4 Nov 1987 & 22 Apr 1994 \\
\hline & & & $X^{a}$ & & $\mathrm{X}$ & & & D11 & 4 Nov 1987 & 22 Apr 1994 \\
\hline \multirow{2}{*}{$\begin{array}{l}\text { Hanford Barrier } \\
\text { w/Gravel Admix }\end{array}$} & 5 & $\mathrm{X}$ & & & & & $\mathrm{X}$ & D2 & 4 Nov 1987 & 22 Apr 1994 \\
\hline & & $\mathrm{X}$ & & & & & $X^{g}$ & D5 & 4 Nov 1987 & 31 Oct 1997 \\
\hline \multirow{3}{*}{$\begin{array}{l}\text { Eroded Hanford } \\
\text { Barrier }\end{array}$} & 6 & $\mathrm{X}$ & & & & & $\mathrm{X}$ & D3 & 4 Nov 1987 & 15 Sep 2010 \\
\hline & & $\mathrm{X}$ & & & & & $\mathrm{X}$ & D6 & 4 Nov 1987 & 27 Feb 1998 \\
\hline & 18 & & & $\mathrm{X}$ & & & $\mathrm{X}$ & D13 & 27 May 1998 & 15 Sep 2010 \\
\hline \multirow[t]{2}{*}{ Gravel Mulch } & 8 & $\mathrm{X}$ & & & $\mathrm{X}$ & & & $\mathrm{C} 1$ & 17 Nov 1989 & 15 Sep 2010 \\
\hline & 10 & & $X$ & & $X$ & & & $\mathrm{C} 4$ & 17 Nov 1989 & 15 Sep 2010 \\
\hline \multirow[t]{2}{*}{ Pit-Run Sand } & 9 & $X$ & & & & & $X^{g}$ & $\mathrm{C} 2$ & 17 Nov 1989 & 15 Sep 2010 \\
\hline & 11 & & $\mathrm{X}$ & & & & $\mathrm{X}$ & $\mathrm{C} 5$ & 17 Nov 1989 & 15 Sep 2010 \\
\hline \multirow[t]{2}{*}{ Basalt Side Slope } & 12 & $\mathrm{X}$ & & & $\mathrm{X}$ & & & D2 & Nov 1994 & 15 Sep 2010 \\
\hline & 13 & & & $\mathrm{X}$ & $\mathrm{X}$ & & & D9 & Nov 1994 & Nov 1998 \\
\hline \multirow{2}{*}{$\begin{array}{l}\text { Sandy Gravel } \\
\text { Side Slope }\end{array}$} & 14 & $\mathrm{X}$ & & & $\mathrm{X}$ & & & D4 & Nov 1994 & 15 Sep 2010 \\
\hline & 15 & & & $X$ & $\mathrm{X}$ & & & D11 & Nov 1994 & 27 Sep 2001 \\
\hline \multirow[t]{2}{*}{ Prototype Barrier } & 16 & $\mathrm{X}$ & & & & & $\mathrm{X}$ & D7 & Nov 1994 & Nov 1998 \\
\hline & 17 & & & $\mathrm{X}$ & & & $\mathrm{X}$ & D14 & Nov 1994 & 31 Aug 2002 \\
\hline \multirow{4}{*}{$\begin{array}{l}\text { Hanford Barrier } \\
\text { Erosion/Dune } \\
\text { Sand Deposition }\end{array}$} & 19 & $\mathrm{X}$ & & & & $X$ & & D5 & 17 Nov 1997 & 15 Sep 2010 \\
\hline & & $\mathrm{X}$ & & & & $X$ & & W2 & 17 Nov 1997 & 15 Sep 2010 \\
\hline & 20 & & & $\mathrm{X}$ & & $\mathrm{X}$ & & D12 & 17 Nov 1997 & 15 Sep 2010 \\
\hline & & & & $\mathrm{X}$ & & $\mathrm{X}$ & & W4 & 17 Nov 1997 & 15 Sep 2010 \\
\hline \multirow{2}{*}{$\begin{array}{l}\text { Sand Dune } \\
\text { Migration }\end{array}$} & 21 & $\mathrm{X}$ & & & & $\mathrm{X}$ & & D6 & 22 Jul 1998 & 15 Sep 2010 \\
\hline & 22 & & & $\mathrm{X}$ & & $\mathrm{X}$ & & D8 & 22 Jul 1998 & 15 Sep 2010 \\
\hline Modified RCRA & 23 & $\mathrm{X}$ & & & & & $\mathrm{X}$ & D7 & 23 Feb 1999 & 15 Sep 2010 \\
\hline $\begin{array}{l}\text { Subtitle C } \\
\text { Barrier }\end{array}$ & 24 & & & $\mathrm{X}$ & & & $X$ & D9 & 23 Feb 1999 & 15 Sep 2010 \\
\hline
\end{tabular}

Note: The shading indicates the current set of tests.

Vegetation symbols: $\mathrm{NV}=$ no vegetation, $\mathrm{SRV}=$ shallow-rooted vegetation, and DRV = deep-rooted vegetation.

Superscripts: "a" = irrigation accelerated until drainage commenced; "g" = sagebrush planted but died, leaving only grasses. 
Table 4.2. Field Lysimeter Test Facility Treatment Descriptions

\begin{tabular}{|c|c|c|}
\hline Treatment Name & Treatment Description & Lysimeter ID \\
\hline Hanford Barrier & $\begin{array}{l}1.5 \mathrm{~m} \text { of silt loam that rests on a sequence of materials } \\
\text { grading from sand to gravel filter layers and finally to } \\
\text { basalt riprap. }\end{array}$ & $\begin{array}{l}\text { W1, C3, D1, } \\
\text { W3, C6 }\end{array}$ \\
\hline Eroded Hanford Barrier & $\begin{array}{l}\text { Similar to the Hanford Barrier test, except that the silt } \\
\text { loam layer thickness is reduced from } 1.5 \text { to } 1.0 \mathrm{~m} \text {. }\end{array}$ & D3, D13 \\
\hline Gravel Mulch & $\begin{array}{l}0.15 \mathrm{~m} \text { of coarse gravel above } 1.35 \mathrm{~m} \text { of screened (to } \\
\text { remove gravel) pit-run sand on top of unscreened pit-run } \\
\text { sand. }\end{array}$ & $\mathrm{C} 1, \mathrm{C} 4$ \\
\hline Pit-Run Sand & $\begin{array}{l}1.5 \mathrm{~m} \text { of screened (to remove gravel) pit-run sand on top } \\
\text { of unscreened pit-run sand. }\end{array}$ & $\mathrm{C} 2, \mathrm{C} 5$ \\
\hline Basalt Side Slope & $\begin{array}{l}1.5 \mathrm{~m} \text { of unscreened basalt riprap. Beneath the basalt } \\
\text { layer is a } 0.15 \text {-m-thick asphaltic concrete layer underlain } \\
\text { by gravel and more basalt riprap. Resting on top of the } \\
\text { asphaltic concrete are about } 2 \text { to } 3 \mathrm{~cm} \text { of silt loam. }\end{array}$ & $\mathrm{D} 2$ \\
\hline Sandy Gravel Side Slope & $\begin{array}{l}1.5 \mathrm{~m} \text { of sandy gravel resting on an asphaltic concrete } \\
\text { layer in a manner similar to the basalt side slope test. }\end{array}$ & D4 \\
\hline $\begin{array}{l}\text { Hanford Barrier Erosion / Dune } \\
\text { Sand Deposition }\end{array}$ & $\begin{array}{l}\text { Similar to the Hanford Barrier test except that the top } 20 \\
\mathrm{~cm} \text { of silt loam are removed and replaced with dune } \\
\text { sand. }\end{array}$ & $\begin{array}{l}\text { D5, W2, D12, } \\
\text { W4 }\end{array}$ \\
\hline Sand Dune Migration & $3 \mathrm{~m}$ of dune sand. & D6, D8 \\
\hline Modified RCRA Subtitle C Barrier & $\begin{array}{l}\text { A barrier design with only } 1 \mathrm{~m} \text { of silt loam. In addition, } \\
\text { the silt layer has two modifications: } 1 \text { ) the upper } 0.5 \mathrm{~m} \\
\text { of silt loam is amended with pea gravel at the rate of } \\
15 \% \text { by weight, and 2) the lower } 0.5 \mathrm{~m} \text { of silt is } \\
\text { compacted to create a low-conductivity layer. }\end{array}$ & D7, D9 \\
\hline
\end{tabular}

\subsubsection{Irrigation}

A key treatment at the FLTF is enhanced precipitation, which is accomplished by irrigating approximately twice monthly in an amount sufficient to bring the monthly total precipitation plus irrigation $(\mathrm{P}+\mathrm{I})$ equal to the target. Figure 4.2 shows that the actual $\mathrm{P}+\mathrm{I}$ in 2010 lagged the target until nearly August and exceeded the target by about $3 \mathrm{~cm}$ by mid-September. Figure 4.2 shows that the actual $\mathrm{P}+\mathrm{I}$ in 2009 also lagged the target, but recovered earlier in the summer than in 2010 and finished the year (2009) about $1.8 \mathrm{~cm}$ above the target. 


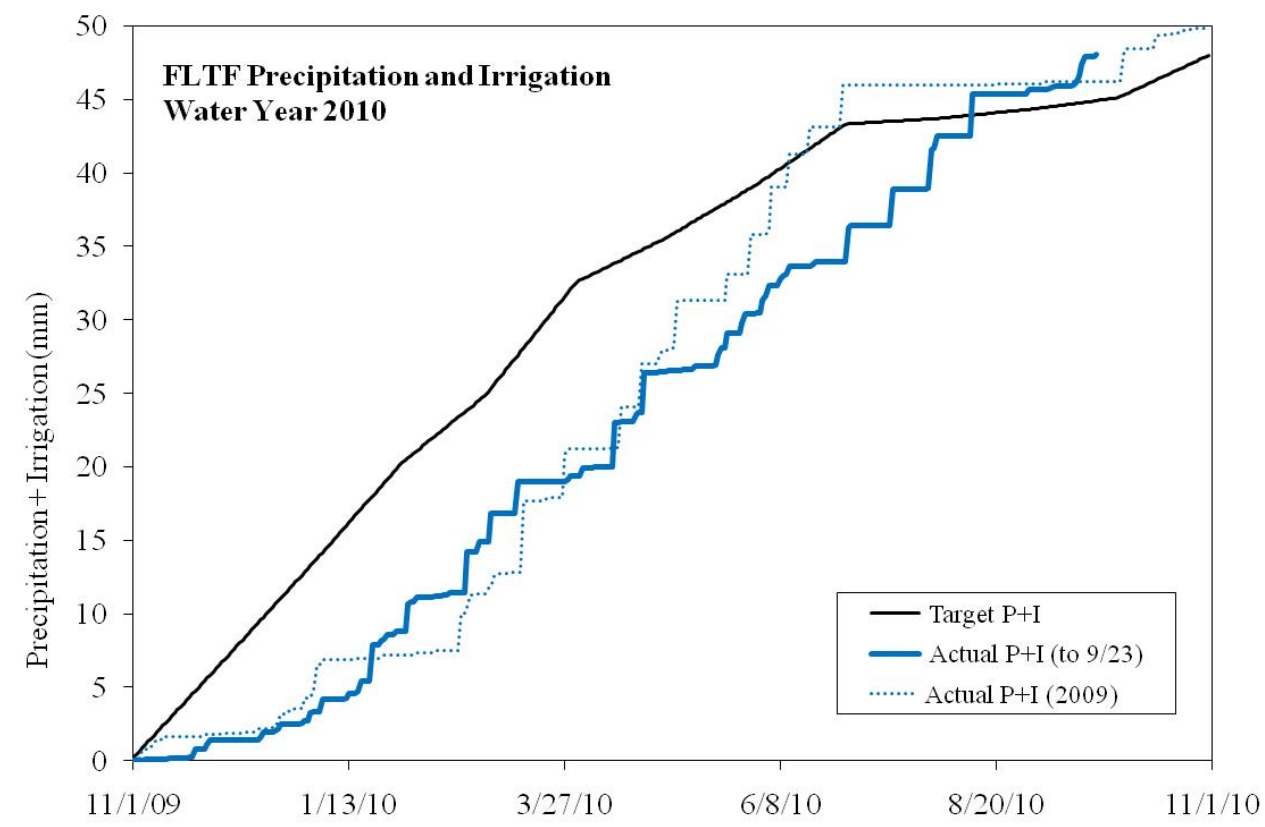

Figure 4.2. Field Lysimeter Test Facility Precipitation and Irrigation Target, Actual in 2010, and Actual in 2009 (target $\mathrm{P}+\mathrm{I}$ is $480 \mathrm{~cm} / \mathrm{yr}$ )

\subsubsection{Drainage}

Figures 4.3 through 4.7 show that drainage in FY 2010 was similar to that of previous years. Table 4.3 shows the long-term drainage rate for each of the tests conducted at the FLTF.

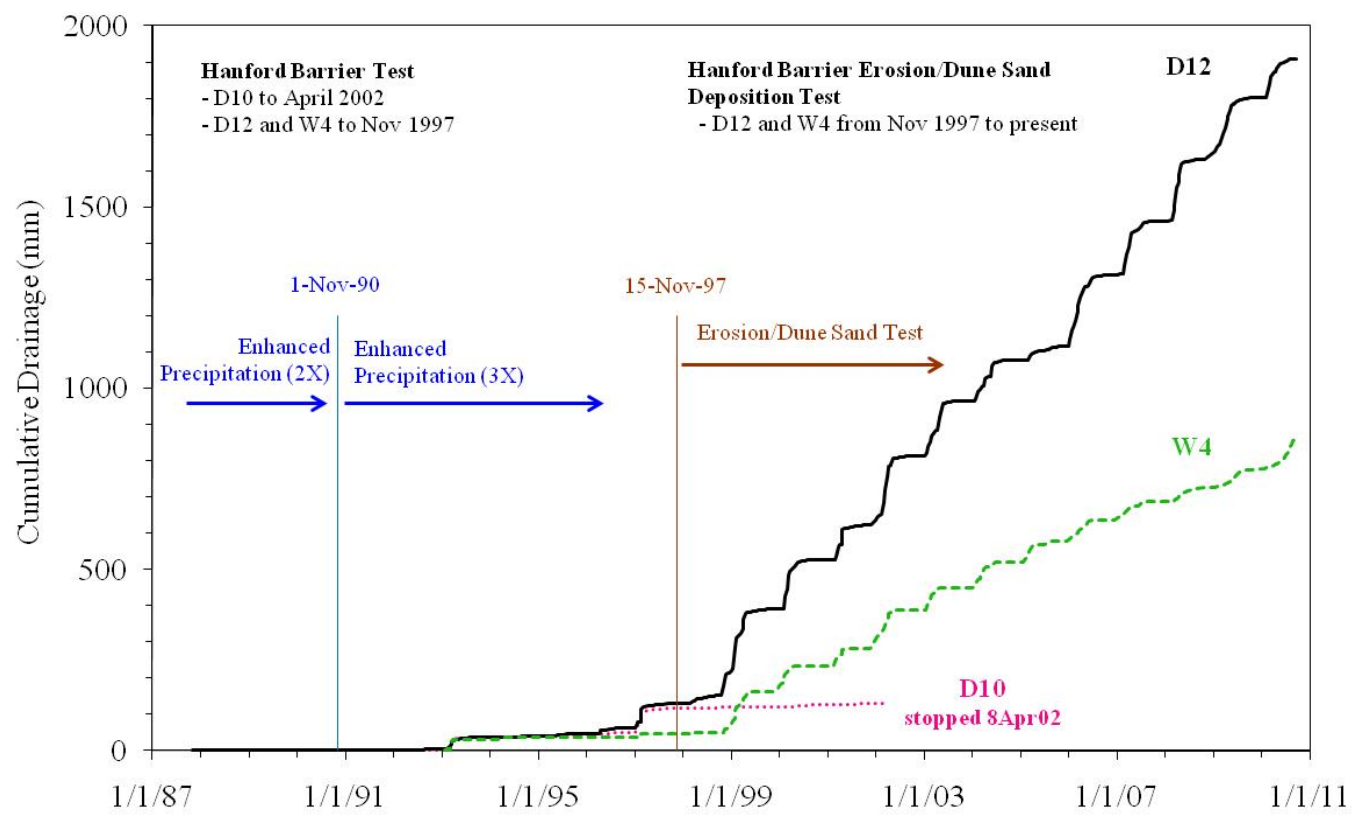

Figure 4.3. Cumulative Drainage from Field Lysimeter Test Facility Caissons D10, D12, and W4 


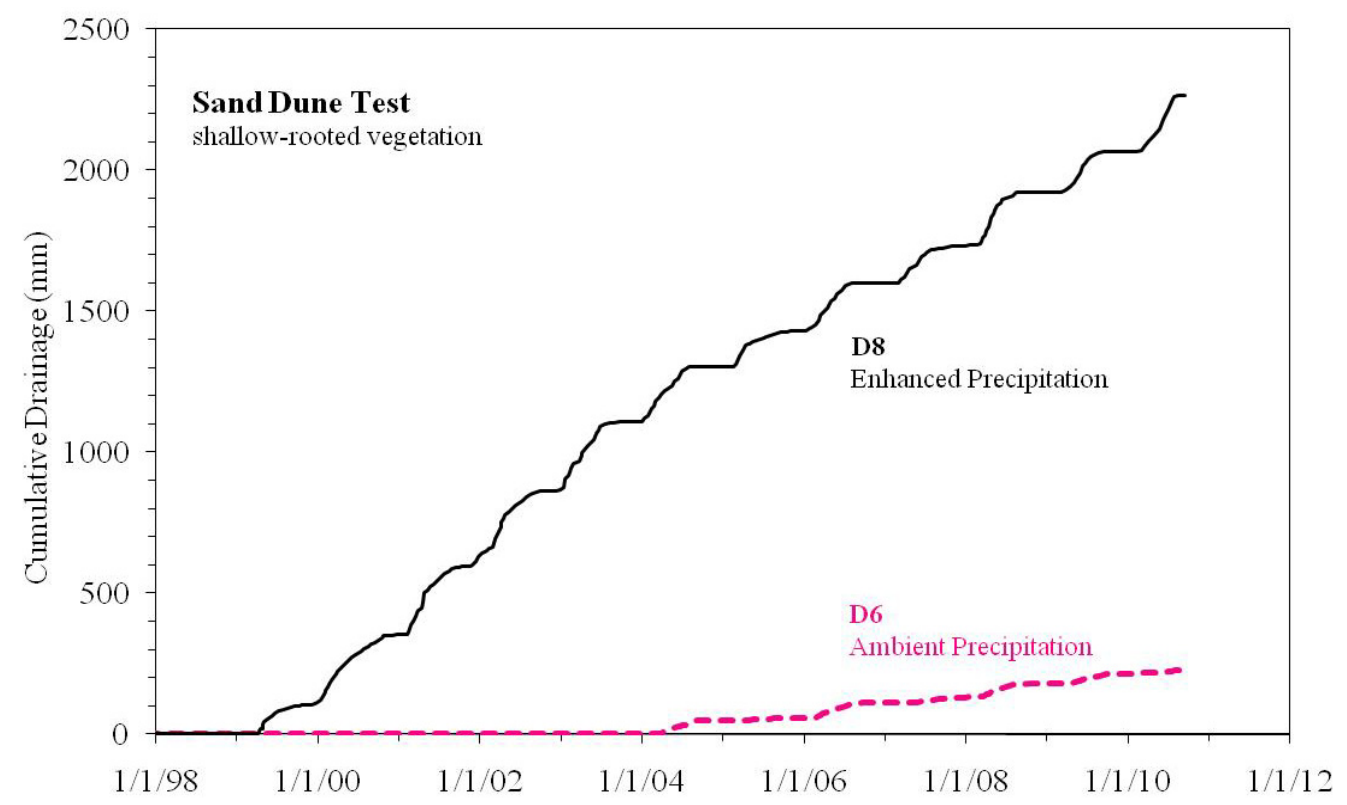

Figure 4.4. Cumulative Drainage from Field Lysimeter Test Facility Caissons D6 and D8

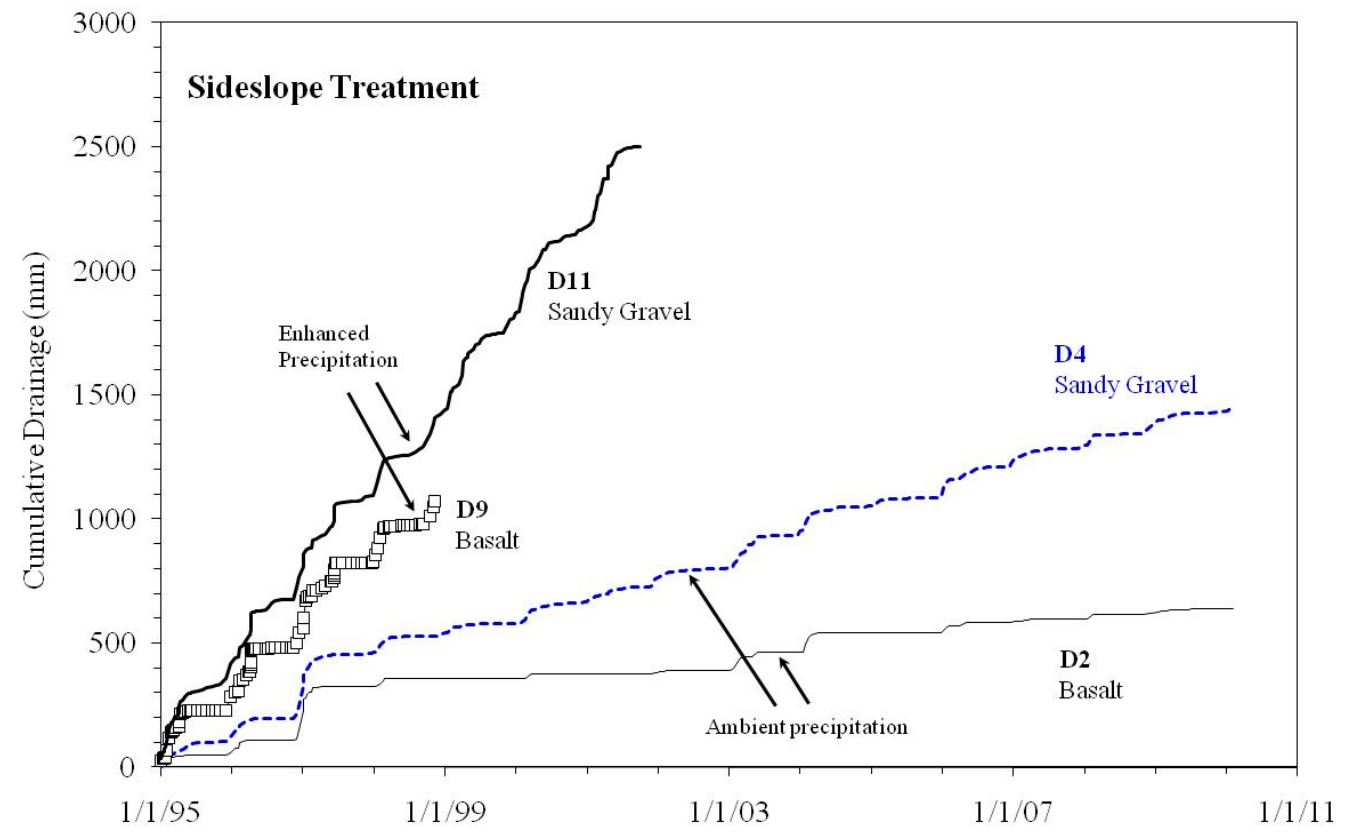

Figure 4.5. Cumulative Drainage from Field Lysimeter Test Facility Lysimeters D2 and D4 


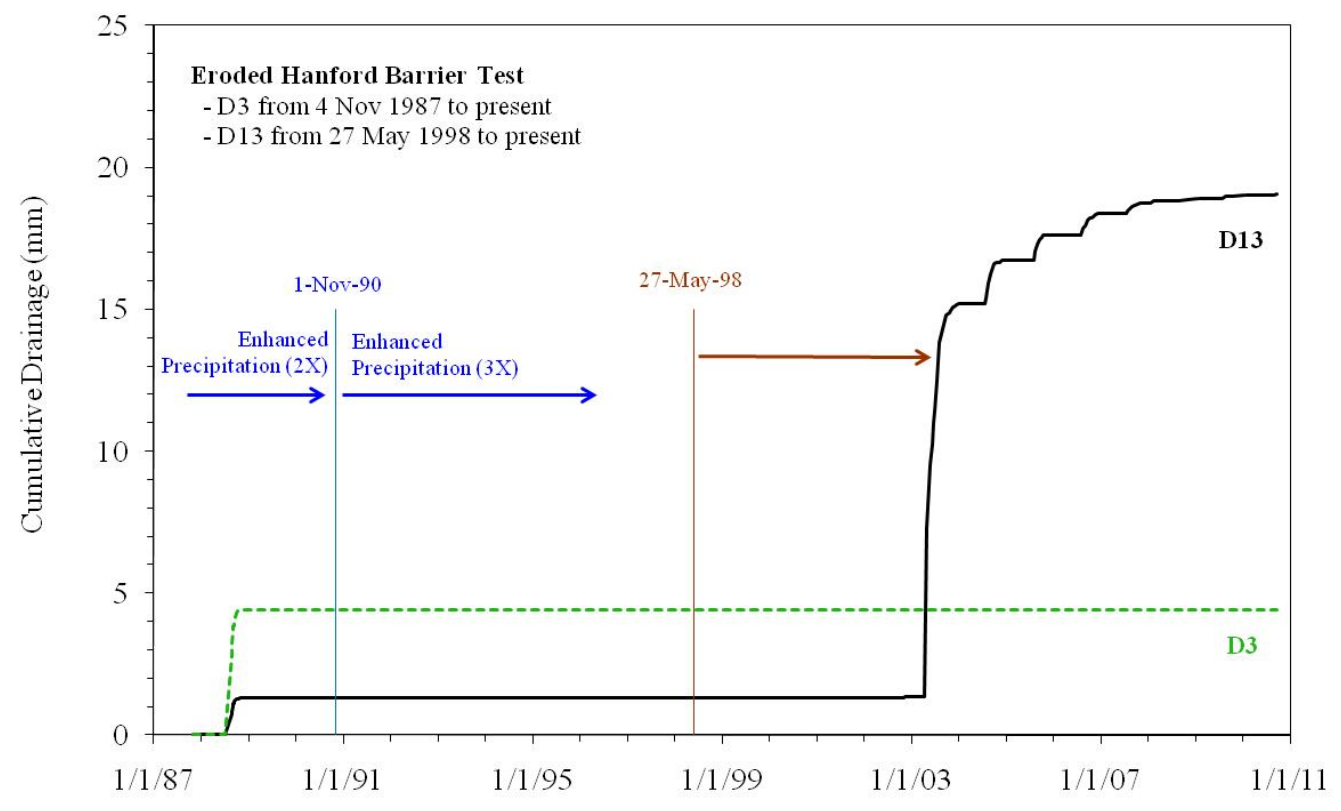

Figure 4.6. Cumulative Drainage from Lysimeters D3 and D13. Cumulative drainage specific to the Eroded Hanford Barrier Test can be calculated by subtracting the initial drainage that occurred during leak testing in 1988.

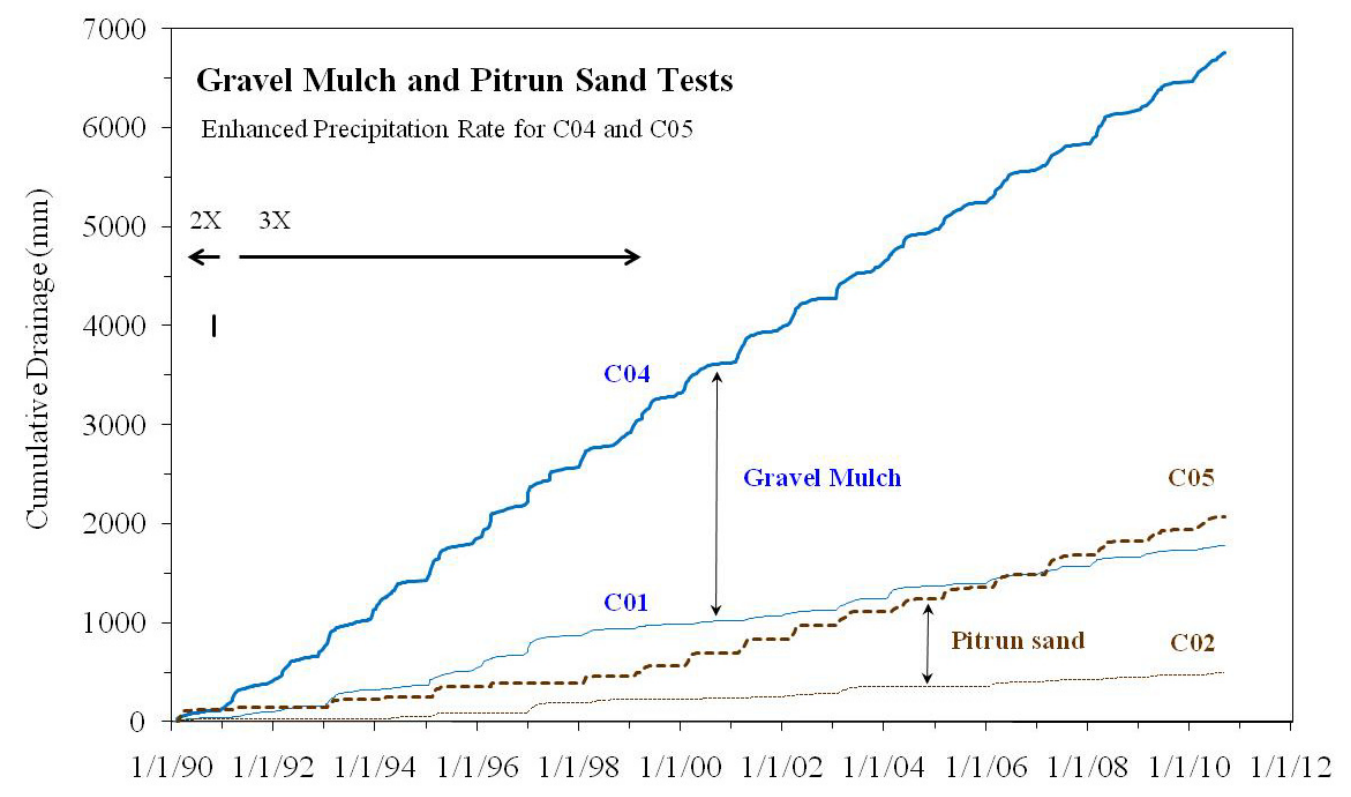

Figure 4.7. Cumulative Drainage from Clear Tube Lysimeters C1, C2, C4, and C5 
Table 4.3. Summary of Treatments Results at the Field Lysimeter Test Facility

\begin{tabular}{|c|c|c|c|c|c|c|}
\hline \multirow[b]{2}{*}{ Test Description } & \multirow{2}{*}{$\begin{array}{l}\text { Treatment } \\
\text { ID No. }\end{array}$} & \multirow{2}{*}{$\begin{array}{l}\text { Lysimeter } \\
\text { ID }\end{array}$} & \multicolumn{3}{|c|}{ Averaging Period } & \multirow{2}{*}{$\begin{array}{l}\text { Average Drainage } \\
(\mathrm{mm} / \mathrm{yr})\end{array}$} \\
\hline & & & Start & End & Duration (yr) & \\
\hline \multirow[t]{14}{*}{ Hanford Barrier } & \multirow{5}{*}{1} & D4 & 2 Jan 1990 & 19 Apr 1994 & 4.3 & 0.0 \\
\hline & & D7 & 2 Jan 1990 & 19 Apr 1994 & 4.3 & 0.0 \\
\hline & & W1 & 4 Nov 1987 & 15 Sep 2010 & 22.9 & 0.0 \\
\hline & & $\mathbf{C 3}$ & 17 Nov 1989 & 15 Sep 2010 & 20.8 & 0.0 \\
\hline & & D1 & 16 Sep 1991 & 15 Sep 2010 & 19.0 & 0.0 \\
\hline & \multirow[t]{2}{*}{2} & D8 & 2 Jan 1990 & 25 Feb 1998 & 8.2 & 0.2 \\
\hline & & W2 & 4 Nov 1987 & 31 Oct 1997 & 10.0 & 0.0 \\
\hline & \multirow{4}{*}{3} & D13 & 2 Jan 1990 & 7 Jan 1998 & 8.0 & 0.0 \\
\hline & & D14 & 2 Jan 1990 & 5 Jan 1994 & 4.0 & 0.0 \\
\hline & & W3 & 4 Nov 1987 & 15 Sep 2010 & 22.9 & 0.0 \\
\hline & & C6 & 17 Nov 1989 & 15 Sep 2010 & 20.8 & 0.0 \\
\hline & \multirow{3}{*}{4} & D10 & 2 Jan 1990 & 10 Jan 2002 & 12.0 & 10.7 \\
\hline & & D12 & 2 Jan 1990 & 31 Oct 1997 & 7.8 & 16.4 \\
\hline & & W4 & 2 Jan 1990 & 31 Oct 1997 & 7.8 & 6.2 \\
\hline \multirow{2}{*}{$\begin{array}{l}\text { Hanford Barrier } \\
\text { w/Gravel Admix }\end{array}$} & \multirow{2}{*}{5} & D2 & 2 Jan 1990 & 19 Apr 1994 & 4.3 & 0.0 \\
\hline & & D5 & 2 Jan 1990 & 31 Oct 1997 & 7.8 & 0.0 \\
\hline \multirow{3}{*}{$\begin{array}{l}\text { Eroded Hanford } \\
\text { Barrier }\end{array}$} & \multirow{2}{*}{6} & D3 & 18 Sep 1990 & 15 Sep 2010 & 20.0 & 0.0 \\
\hline & & D6 & 2 Jan 1990 & 25 Feb 1998 & 8.2 & 0.0 \\
\hline & 18 & D13 & 11 Sep 1998 & 15 Sep 2010 & 11.0 & 1.5 \\
\hline \multirow[t]{2}{*}{ Gravel Mulch } & 8 & $\mathrm{C} 1$ & 18 Sep 1990 & 15 Sep 2010 & 20.0 & 84.4 \\
\hline & 10 & $\mathrm{C} 4$ & 18 Sep 1990 & 15 Sep 2010 & 20.0 & 317 \\
\hline \multirow[t]{2}{*}{ Pit-Run Sand } & 9 & $\mathrm{C2}$ & 18 Sep 1990 & 15 Sep 2010 & 20.0 & 22.6 \\
\hline & 11 & C5 & 18 Sep 1990 & 15 Sep 2010 & 20.0 & 90.7 \\
\hline \multirow[t]{2}{*}{ Basalt Side Slope } & 12 & D2 & 22 Sep 1995 & 15 Sep 2010 & 15.0 & 39.9 \\
\hline & 13 & D9 & 4 Jan 1995 & 24 Nov 1998 & 3.9 & 269 \\
\hline \multirow{2}{*}{$\begin{array}{l}\text { Sandy Gravel } \\
\text { Side Slope }\end{array}$} & 14 & D4 & 22 Sep 1995 & 15 Sep 2010 & 15.0 & 94.5 \\
\hline & 15 & D11 & 4 Jan 1995 & Sep 2001 & 6.8 & 365 \\
\hline \multirow[t]{2}{*}{ Prototype Barrier } & 16 & D7 & 4 Jan 1995 & 24 Nov 1998 & 3.9 & 0.0 \\
\hline & 17 & D14 & 4 Jan 1995 & 28 Aug 2002 & 7.7 & 0.0 \\
\hline \multirow{4}{*}{$\begin{array}{l}\text { Hanford Barrier } \\
\text { Erosion/Dune } \\
\text { Sand Deposition }\end{array}$} & \multirow{2}{*}{19} & D5 & 11 Sep 1998 & 15 Sep 2010 & 12.0 & 0.29 \\
\hline & & W2 & 11 Sep 1998 & 15 Sep 2010 & 12.0 & 0.0 \\
\hline & \multirow{2}{*}{20} & D12 & 11 Sep 1998 & 15 Sep 2010 & 12.0 & 148 \\
\hline & & W4 & 11 Sep 1998 & 15 Sep 2010 & 12.0 & 67.8 \\
\hline \multirow{2}{*}{$\begin{array}{l}\text { Sand Dune } \\
\text { Migration }\end{array}$} & 21 & D6 & 15 Sep 1999 & 15 Sep 2010 & 11.0 & 20.7 \\
\hline & 22 & D8 & 15 Sep 1999 & 15 Sep 2010 & 11.0 & 197 \\
\hline \multirow{2}{*}{$\begin{array}{l}\text { Modified RCRA } \\
\text { Subtitle C Barrier }\end{array}$} & 23 & D7 & 15 Sep 1999 & 15 Sep 2010 & 11.0 & 0.00 \\
\hline & 24 & D9 & 15 Sep 1999 & 15 Sep 2010 & 11.0 & 0.03 \\
\hline
\end{tabular}

Note: The shading and bolding indicate the current set of tests.

Precipitation symbols: ambient $=$ natural precipitation; $2 \mathrm{x} / 3 \mathrm{x}=$ ambient precipitation plus irrigation so that total water received is equivalent to $2 \mathrm{x}$ (or $3 \mathrm{x}$ ) the average annual precipitation (considered to be $160 \mathrm{~mm} / \mathrm{yr}$ ); for some tests, the precipitation treatment started as $2 \mathrm{x}$ and was switched on 1 November 1990 to $3 \mathrm{x}$. 


\subsubsection{Matric Head}

Matric head was typically measured at the same time drainage was measured. Figure 4.8 shows the seasonal variations of matric head at three depths in the sand dune test lysimeters D6 and D8 during the most recent 3-year period. The data show decreasing heads as each summer progresses and increasing heads during the winters. Vegetation on these two lysimeters has been very sparse every year, so the summer decrease has not been that great. In fact, at the $210-\mathrm{cm}$ depth, matric heads have changed very little. Also apparent in Figure 4.8 is the noise in each data series. The noise is a result of the measurement technique (traditional water-filled tensiometer; septum; transducer), operator differences, and infrequency of measurement. Such noise is difficult to model. It would be fruitful to examine alternative methods for measuring matric heads and automating the data collection.

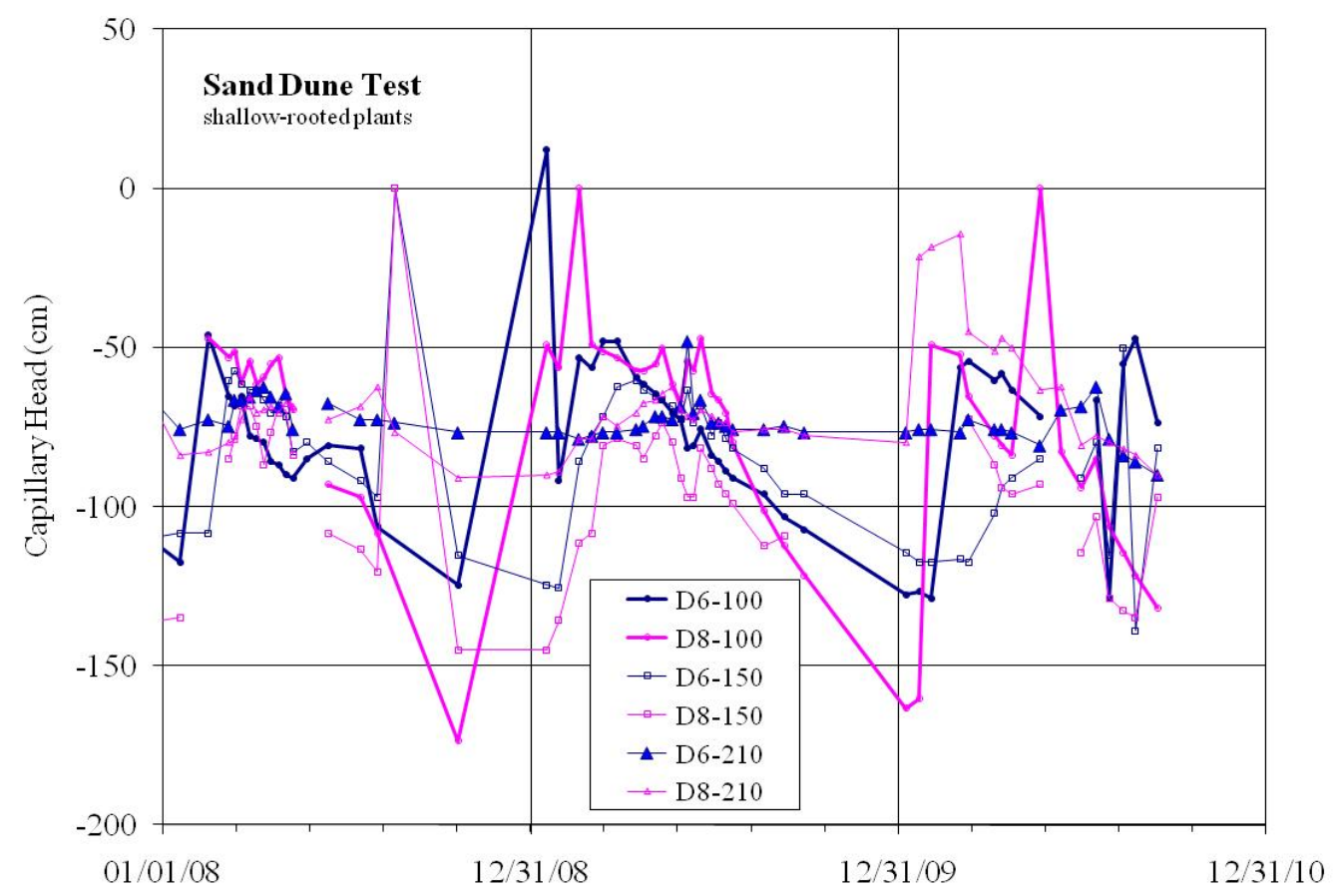

Figure 4.8. Matric Heads in the Sand Dune Test at Depths of 100, 150, and $210 \mathrm{~cm}$

\subsubsection{Chloride}

The chloride concentration in drainage water can be used to estimate the atmospheric deposition rate, which is important to the calculation of recharge using the chloride mass balance method. Samples were analyzed for chloride and other anions in August 2010. Table 4.4 shows the results along with data from previous years. Because it was toward the end of summer, we were unable to get drainage from six of the lysimeters.

During August 2010, two samples were collected from each lysimeter during a normal drainage collection activity. One sample was collected after $20 \mathrm{ml}$ of drainage were allowed to flow (to eliminate possible drain tube effects), and the second sample was collected as the drainage rate started to subside. The results were mixed. Lysimeters $\mathrm{C} 1$ and $\mathrm{C} 4$ yielded decreases in chloride concentration of $3.6 \%$ and $27 \%$ between the beginning and ending sampling. Lysimeters D12 and W4 yielded increases of 
$8.3 \%$ and $5.8 \%$. The differences are larger than expected, but the number of samples is too small from which to draw conclusions. This exercise could be repeated several times and for more lysimeters to determine whether an effect exists.

Seasonal changes in precipitation and evapotranspiration have the potential to result in seasonal changes in chloride concentration. However, the methodology used to date is not able to discern seasonal changes. To quantify any season impact, the sampling exercise could be conducted multiple times during a year.

Table 4.4. Chloride Concentrations Measured in Field Lysimeter Test Facility Lysimeter Drainage Waters. The highlighted sampling dates are corrected from previously-published dates)

\begin{tabular}{ccccc}
\hline \multirow{2}{*}{$\begin{array}{c}\text { Lysimeter } \\
\text { ID }\end{array}$} & July 2, 2007 & August 18, 2007 & June 29, 2009 & August 24, 2010 \\
\cline { 2 - 5 } C1 & 2.87 & 2.43 & 2.20 & 2.27 \\
C2 & 5.39 & 7.82 & -- & -- \\
C4 & -- & -- & 2.00 & 2.74 \\
C5 & -- & -- & 3.92 & -- \\
D2 & -- & -- & 48.20 & -- \\
D4 & 1.23 & 1.36 & 1.35 & -- \\
D6 & 254.06 & 88.90 & 67.70 & -- \\
D8 & -- & -- & 1.87 & -- \\
D12 & -- & -- & 1.70 & 0.42 \\
W4 & -- & -- & 2.88 & 3.02 \\
\hline
\end{tabular}

\subsection{Field Lysimeter Test Facility Pit}

The FLTF Pit site is on the north side of the FLTF and is a collection of four cement caissons containing WFMs packed with different soil types. Table 4.5 shows the treatments, monitoring periods, and average drainage rates. The gravel soil is similar to the gravel material in the FLTF D4 lysimeter (Sandy Gravel Side Slope Test). The silt loam soil is from the same source as that used in the FLTF Hanford Barrier treatments. The sand soil is similar to the FLTF Dune Sand Migration test (D6 and D8 lysimeters) soil. The 5/8-in. minus material is similar to the commercial road base material existing on the surfaces of many Hanford tank farms. All WFMs have the divergence columns at the soil surface, with the exception of one silt loam WFM that has the divergence column at $1 \mathrm{~m}$ below the soil surface. Table 4.5 shows that the silt loam treatments yielded no drainage, and the sand and gravel treatments yielded the highest drainage. When silt loam was blended into either sand or gravel, the drainage rate was reduced by about $50 \%$.

Figure 4.9 shows that drainage was detected in 2010 in only WFM 4 (Sand) and WFM 6 (5/8-in. minus material, also called road base). The drainage amounts were 0.4 and $1.6 \mathrm{~mm}$. When annualized, they represent rates of 0.7 and $2.4 \mathrm{~mm} / \mathrm{yr}$, respectively. These rates are much lower than those in 
previous years, as shown in Table 4.5. In previous years, WFMs 5 and 7 had rates of about $15 \mathrm{~mm} / \mathrm{yr}$; in 2010, the rates were zero. Most surprisingly, WFM 1 had the highest rate in previous years $(49.3 \mathrm{~mm} / \mathrm{yr})$, yet had zero drainage in 2010. This seemingly anomalous behavior suggests the WFMs are not functioning correctly and need to be checked. Authors of previous studies also reported difficulties with WFMs, and it may be time to reconsider their use for this project.

Table 4.5. FLTF Pit Treatments, Monitoring Periods, and Average Drainage Rates for a Subset of Data. All WFMs in the FLTF pit are unvegetated (after Rockhold et al. 2009). The highlighted values are corrected from previously published values, which were $30 \%$ lower.

\begin{tabular}{|c|c|c|c|}
\hline $\begin{array}{l}\text { Water Flux } \\
\text { Meter ID }\end{array}$ & Soil Description & Monitoring Period & $\begin{array}{l}\text { Average Drainage } \\
\text { Rate (mm/yr) from } \\
1 \text { Jan } 2006 \text { to } \\
14 \text { August } 2009\end{array}$ \\
\hline 1 & Sandy gravel & Nov 2001-present & 49.3 \\
\hline 2 & Silt loam & Nov 2001-present & 0 \\
\hline 3 & Silt loam (1 m) & Nov 2001-present & 0 \\
\hline 4 & Sand & Nov 2001-present & 34.3 \\
\hline 5 & $80 \%$ sand, $20 \%$ silt loam (wt $\%$ ) & Jun 2004-present & 15.5 \\
\hline 6 & 5/8-in. minus material & Jun 2004-present & 31.1 \\
\hline 7 & $\begin{array}{l}80 \% 5 / 8 \text {-in. minus material } \\
20 \% \text { silt loam (wt } \%)\end{array}$ & Jun 2004-present & 15.6 \\
\hline
\end{tabular}

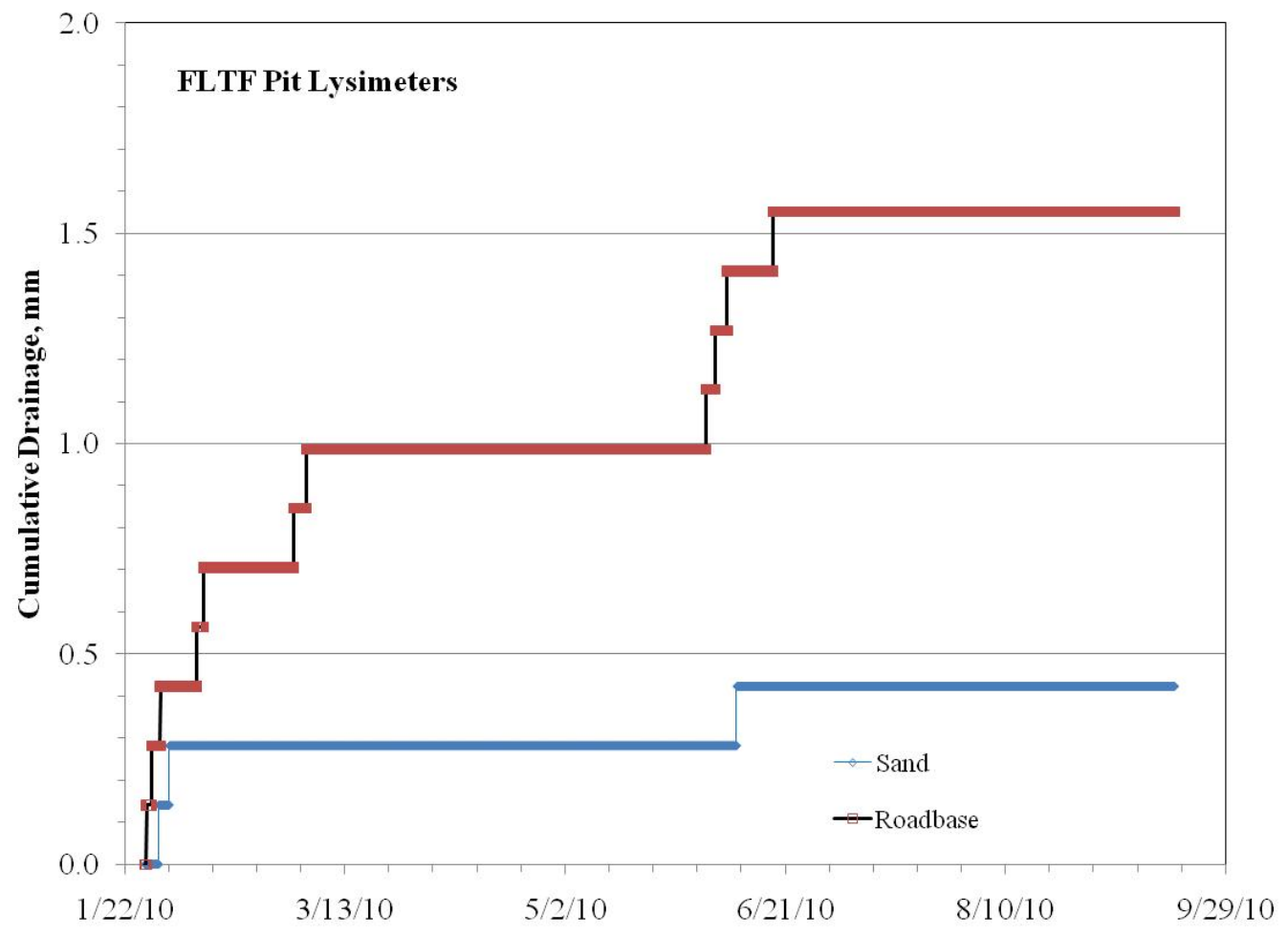

Figure 4.9. Cumulative Drainage from Water Flux Meters at the Field Lysimeter Test Facility Pit Site 


\subsection{Integrated Disposal Facility Dune Site}

Water contents at the IDF Dune Site are monitored only when weather conditions indicate there might be significant recharge. As noted in Section 3, weather conditions during FY 2010 were not conducive to recharge, so this site was not monitored. In October 2010, we will monitor the site to establish water conditions prior to entering the 2010-2011 winter season.

\subsection{Solid Waste Landfill Lysimeter}

Figure 4.10 shows that drainage from the SWL lysimeter continues to be high. From September 1996 to September 2010, the year-to-year drainage rate varied depending on weather conditions, but the average rate for the entire period was $48.2 \mathrm{~mm} / \mathrm{yr}$. The WFM data for this site are not reported. As noted by Rockhold et al. (2009), the WFMs at this site have not been operating as expected. In addition, the coarse gravel surfaces and lack of vegetation are not representative of conditions above the SWL lysimeter. Furthermore, we understand that the SWL is scheduled to receive a final cover soon. Given these issues, we recommend that WFM monitoring of this site be discontinued.

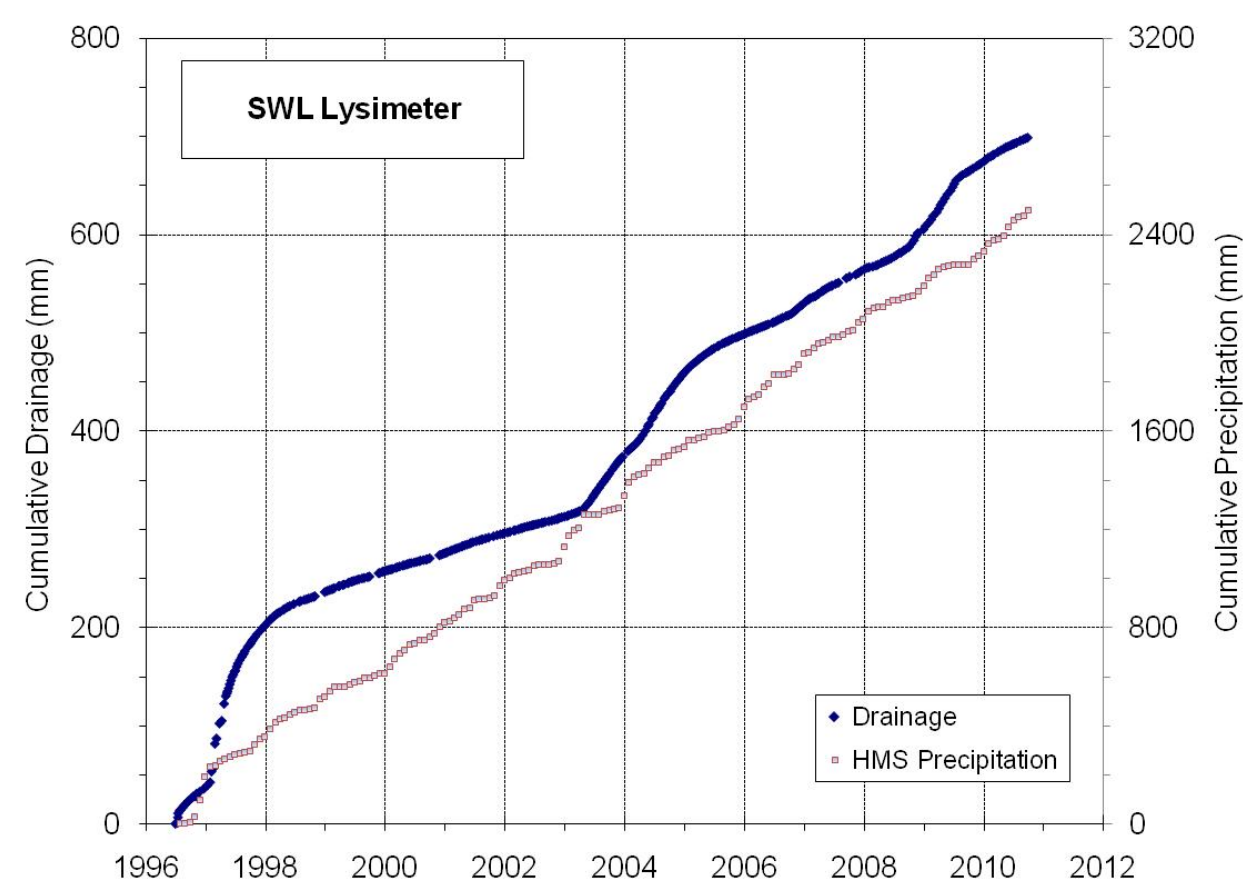

Figure 4.10. Cumulative Drainage from the Solid Waste Landfill Lysimeter

\subsection{North Lysimeter Site}

The 300 North Area lysimeter site is about $10 \mathrm{~km}$ north of Richland, Washington, just south of the Fast Flux Test Facility and within $300 \mathrm{~m}$ of the 300 Area Burial Grounds (618-10). A set of eight lysimeters was constructed at this site in 1978 to simulate water-balance conditions of waste burial grounds with bare, coarse-grained surfaces. Monitoring of natural recharge (deep drainage) at this site is restricted to one of these lysimeters (i.e., the south caisson). The south caisson lysimeter is filled with Hanford formation sediment screened to contain less than $1 \%$ gravel (i.e., material $>2 \mathrm{~mm}$ ). The 
lysimeter has remained essentially void of vegetation over its lifetime. A tipping-bucket rain gauge was installed at the drainage outlet at the bottom of the lysimeter in August 2000 and connected to a data logger to measure drainage on a continuous basis. In April 2002, two WFMs also were installed in the south caisson and connected to the datalogger. Water content and matric potential profiles within the south caisson lysimeter are also monitored, as is matric potential outside the lysimeter at the 7.5-m depth.

Figure 4.11 shows that, as expected, the water content response was greatest at the shallowest depth $(30 \mathrm{~cm})$ and least at the deepest depth $(90 \mathrm{~cm})$. The May-June peak at all three depths is a response to higher than normal precipitation during that period. Even so, the water contents at the deeper depths are lower by 0.02 to 0.03 volume fraction than they were during the same period in the previous 2 years, which may reflect the somewhat lower than normal precipitation over that period.

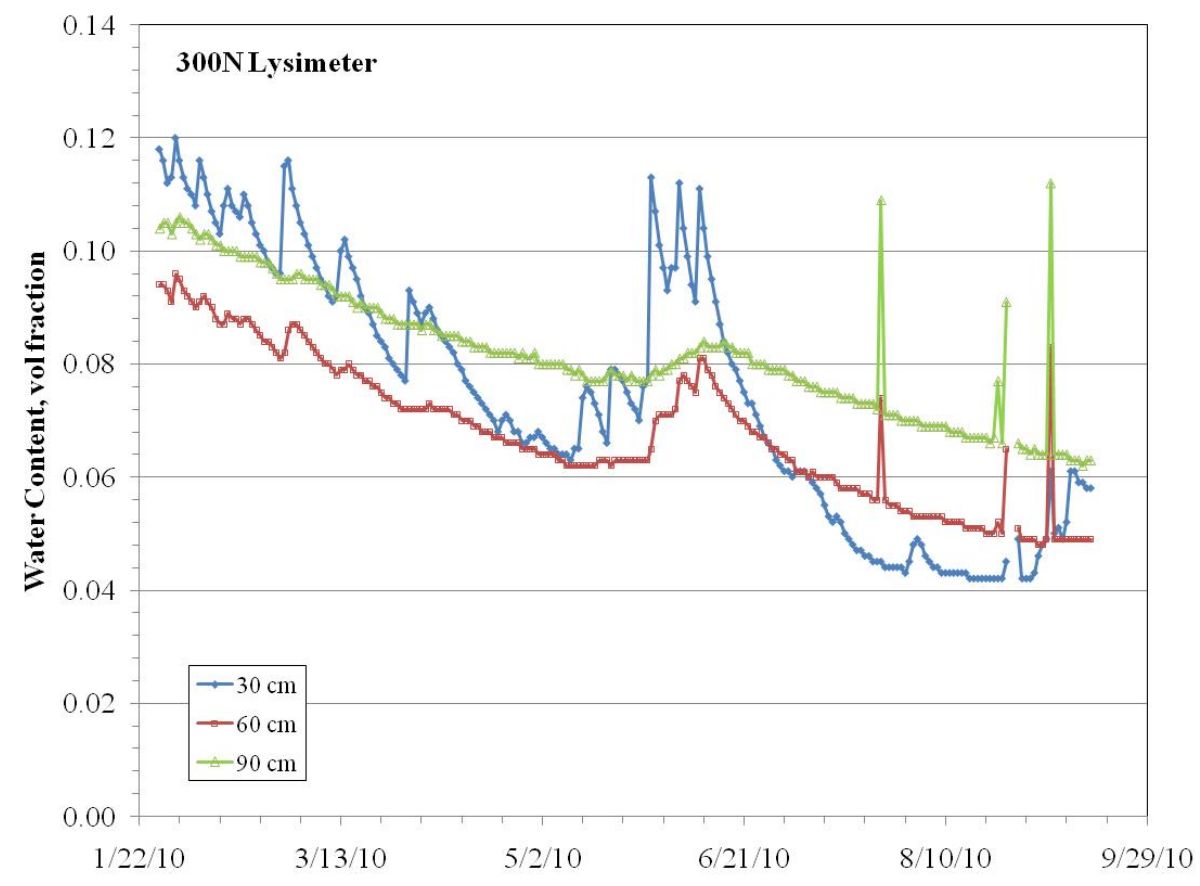

Figure 4.11. Water Content Variations at Three Depths in the 300 North Lysimeter in 2010

\subsection{Grass Site}

The Grass Site is approximately $4.5 \mathrm{~km}$ northwest of the 300 Area in a location dominated by stabilized sand dunes. Layered soil conditions exist at the site. A sandy loam to loamy sand soil is present from the surface to a depth of approximately $40 \mathrm{~cm}$. Beneath that surface layer is coarser sandy soil. Vegetation at the Grass Site is predominantly annual and perennial grass. In 2005, a recharge monitoring station was installed at this location; the station consisted of two WFMs and two water content sensors. The WFMs were installed with the layered soil intact.

Figure 4.12 shows that water content decreased through much of 2010. Higher than normal precipitation in May and June caused water content to rise at the $30-\mathrm{cm}$ depth, but there was very little response at $60 \mathrm{~cm}$. A similar response was noted in 2007, 2008, and 2009. The muted response at $60 \mathrm{~cm}$ suggests that the natural capillary break between the upper and lower sand layers may have prevented water from draining deeper into the profile, thus reducing recharge. Compare this response with that in 
the 300 North lysimeter, in which water contents at both 60 and $90 \mathrm{~cm}$ responded noticeably to the May precipitation. Both WFMs at the Grass Site indicated no drainage in 2010. WFM 1 has not detected drainage since early 2006, while WFM 2 detected about $1.7 \mathrm{~mm}$ of drainage in early 2009 and none at any other time since early 2006. Because of the erratic behavior of two seemingly identical WFMs, both WFMs need to be field-checked to confirm they are functioning.

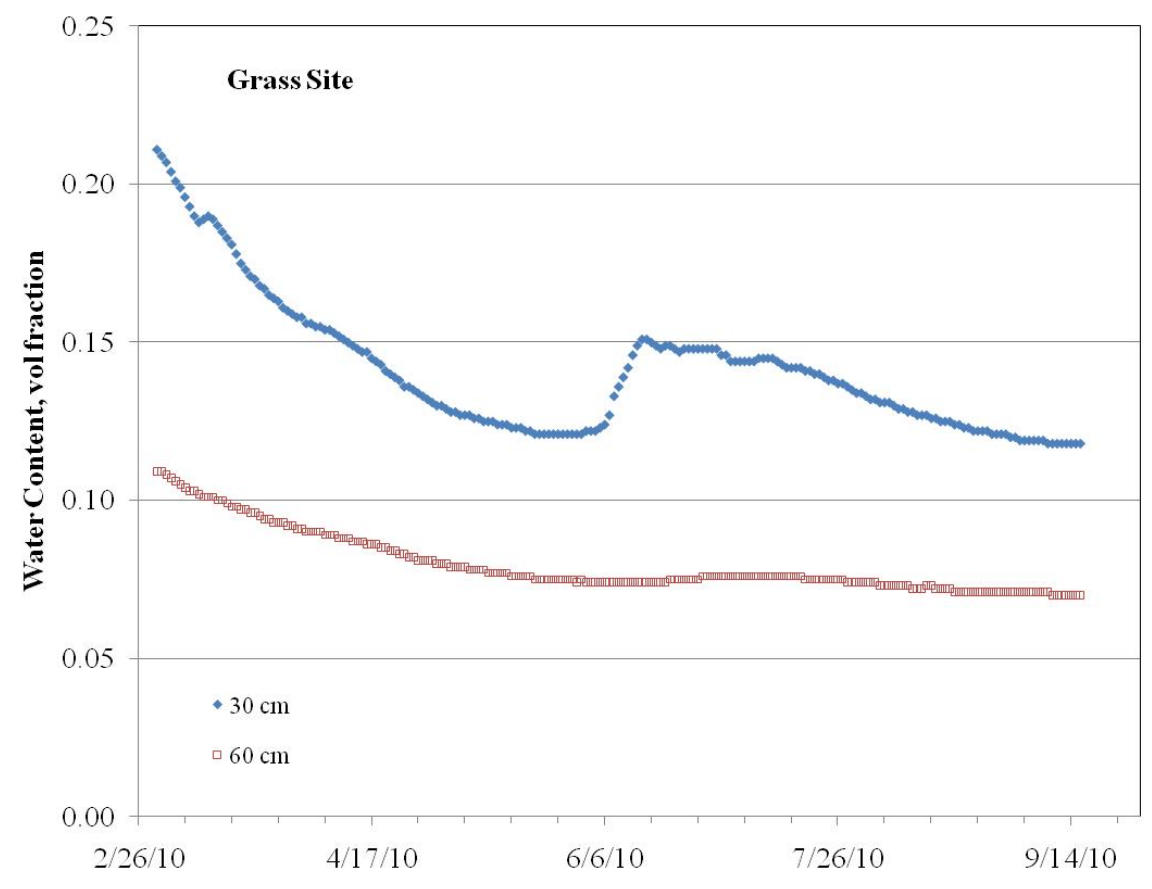

Figure 4.12. Water Content at Two Depths at the Grass Site in 2010 



\subsection{Recharge Strategy for 2011-2015}

Much has been learned in the past 30 years about recharge at the Hanford Site. We have a good understanding of recharge for some combinations (e.g., graveled surfaces; silt loam barriers) but insufficient understanding for others (e.g., disturbed areas that have been revegetated). One of the challenges of recharge estimation is that the available resources and time are limited. Thus, to provide recharge estimates for the much larger number of soil conditions as well as scenarios involving soil, vegetation, and climate combinations, we need to understand all the issues. Through that understanding, we can prioritize activities to collect the information that will provide the most value to making remediation and closure decisions. This section discusses data gaps, project leveraging, and recommendations for existing monitoring sites.

\subsection{Data Gaps}

Table 5.1 contains a set of previously-identified data gaps related to recharge at the Hanford Site (Rockhold et al. 2009; Nichols et al. 2008). We reviewed those gaps and identified those that rank higher in importance than the rest. For each gap, we identified the issue and provided a recommendation for resolving (or at least starting to resolve) the issue.

\subsection{Leverage}

Characterizing recharge for the myriad site conditions and potential future scenarios would be prohibitively costly and unnecessary. This project should focus on measuring recharge well for a set of conditions and using models to extend those recharge data to unmonitored sites and conditions. We also recommend leveraging the work of other projects as much as possible. A great example of this approach is the leachate monitoring conducted by CHPRC at the SWL site. Another is the Prototype Hanford Barrier project, which provides monitoring data for drainage through a surface barrier and through its side slopes (Ward et al. 2007). Other opportunities include planned remediation monitoring and opportunistic vadose zone sampling for tracer analysis of recharge. Where the recharge project ought to focus resources is on recharge data acquisition for conditions and scenarios that are considered important to DOE and which are not adequately addressed by other projects.

\subsection{Recommendations for Existing Monitoring Sites}

\subsubsection{Field Lysimeter Test Facility}

We recommend that monitoring at the FLTF be continued for a subset of lysimeters identified in Table 5.2. Of the 14 drainage lysimeters at the FLTF, three are available immediately for other uses and a fourth is recommended to be made available. We recommend that some of the data-logging equipment be replaced once the vendor releases a new model that performs the functions needed to operate at the FLTF. The new model is expected to be released in FY 2011.

In addition to changing the test matrix and conducting maintenance, we recommend that several lysimeters be instrumented with the same water content and matric potential sensors deployed in tank 
farms (interim covers) and BC Cribs (desiccation). These sensors would provide model comparison information, real-time automated measurements, an opportunity to cross-calibrate with the neutron probe, and the ability to compare estimates of recharge flux with measured drainage rates.

Finally, we recommend that analysis of chloride in drainage water continue and be expanded to multiple times during a year to quantify the impact of seasonal weather conditions on chloride concentration in drainage water.

Table 5.1. Ranking of Recharge Data Gaps (issues are more fully explained in Rockhold et al. 2009)

\begin{tabular}{|c|c|c|}
\hline Recharge Data Gap & Issue & Recommendation \\
\hline \multicolumn{3}{|c|}{ Primary Gaps } \\
\hline Soil, vegetation, and land-use maps & $\begin{array}{l}\text { Current maps of soils, vegetation, } \\
\text { and land use at the Hanford Site are } \\
\text { either outdated or lack desired } \\
\text { accuracy due to limited ground } \\
\text { truth data and changing surface } \\
\text { conditions related to site operations }\end{array}$ & $\begin{array}{l}\text { Conduct a modern soil survey } \\
\text { tailored to identify soil types based } \\
\text { on their recharge potential (e.g., } \\
\text { layering features within } \sim 5 \mathrm{~m} \text { of the } \\
\text { surface) }\end{array}$ \\
\hline Climate and ecological change & $\begin{array}{l}\text { Recharge will be a direct function } \\
\text { of future climatic conditions, which } \\
\text { are not known }\end{array}$ & $\begin{array}{l}\text { Develop coherent and consistent } \\
\text { framework to describe the climate, } \\
\text { vegetation, and animal changes } \\
\text { expected at the Hanford Site for as } \\
\text { long as the site is considered a risk }\end{array}$ \\
\hline Natural systems & $\begin{array}{l}\text { Few data exist to characterize } \\
\text { recharge of natural systems }\end{array}$ & $\begin{array}{l}\text { Identify methods and sites to } \\
\text { increase characterization of } \\
\text { recharge in primary soil types: } \\
\text { Rupert sand, Ephrata sandy loam, } \\
\text { and Burbank loamy sand }\end{array}$ \\
\hline $\begin{array}{l}\text { Sensitivity to duration of } \\
\text { measurement record }\end{array}$ & $\begin{array}{l}\text { Infrequent events control recharge } \\
\text { in the arid environment at the } \\
\text { Hanford Site }\end{array}$ & $\begin{array}{l}\text { Extend measurement efforts to } \\
\text { include multiple high-precipitation } \\
\text { periods }\end{array}$ \\
\hline Vegetated disturbed areas & $\begin{array}{l}\text { Lack of recharge data for areas with } \\
\text { disturbed soils that no longer } \\
\text { resemble known soil types }\end{array}$ & $\begin{array}{l}\text { Identify methods and sites to } \\
\text { increase characterization of } \\
\text { recharge in disturbed soils }\end{array}$ \\
\hline \multicolumn{3}{|c|}{ Secondary Gaps } \\
\hline Basalt outcrops & $\begin{array}{l}\text { Higher elevations and unique } \\
\text { surface conditions (deep, thin, or no } \\
\text { soil) of basalt outcrops may } \\
\text { produce recharge rates higher than } \\
\text { those of the surrounding terrain }\end{array}$ & $\begin{array}{l}\text { Characterize soil thickness } \\
\text { variability on Gable Mountain to } \\
\text { estimate the soil water storage } \\
\text { capability and improve recharge } \\
\text { estimation }\end{array}$ \\
\hline Structures & $\begin{array}{l}\text { Roadways, parking lots, and } \\
\text { buildings have the potential to } \\
\text { contribute disproportionately to } \\
\text { recharge through focused } \\
\text { infiltration resulting from runoff } \\
\text { from these surfaces }\end{array}$ & $\begin{array}{l}\text { Prepare strategy for characterizing } \\
\text { recharge potential of structures }\end{array}$ \\
\hline Transformation of gravel surfaces & $\begin{array}{l}\text { Manner and rate of change of } \\
\text { existing gravel-covered surfaces is } \\
\text { unknown }\end{array}$ & $\begin{array}{l}\text { Identify methods and sites to } \\
\text { characterize manner and rate of } \\
\text { change of gravel-covered surfaces }\end{array}$ \\
\hline
\end{tabular}


Table 5.1. (contd)

\begin{tabular}{|c|c|c|}
\hline Recharge Data Gap & Issue & Recommendation \\
\hline $\begin{array}{l}\text { Gravel-covered waste management } \\
\text { areas }\end{array}$ & $\begin{array}{l}\text { Tank farm surfaces have more fines } \\
\text { than the lysimeters used to } \\
\text { characterize recharge }\end{array}$ & $\begin{array}{l}\text { Modify existing lysimeters to } \\
\text { provide more representative } \\
\text { estimates of recharge }\end{array}$ \\
\hline Surface barriers & $\begin{array}{l}\text { Functional lifetime of surface } \\
\text { barriers is not well defined or } \\
\text { supported; little to no performance } \\
\text { data to support new designs; no } \\
\text { agreed-upon set of degradation } \\
\text { scenarios; consensus is lacking on } \\
\text { how to represent barrier } \\
\text { performance after the design life }\end{array}$ & \\
\hline Subsurface ecology & $\begin{array}{l}\text { Plant roots and animal burrowing } \\
\text { can affect recharge, more so for } \\
\text { surface barriers with thinner surface } \\
\text { layers }\end{array}$ & \\
\hline Uncertainty & $\begin{array}{l}\text { Limited set of recharge data for all } \\
\text { surface conditions hampers the } \\
\text { calculation of a stochastic } \\
\text { distribution of recharge }\end{array}$ & $\begin{array}{l}\text { Increase recharge data sets for } \\
\text { multiple surface types }\end{array}$ \\
\hline Modern chloride deposition & $\begin{array}{l}\text { Facilities (e.g., coal plants) may } \\
\text { have been possible local sources of } \\
\text { atmospheric chloride, which would } \\
\text { affect chloride-based estimates of } \\
\text { recharge }\end{array}$ & $\begin{array}{l}\text { Outline strategy to confirm and } \\
\text { quantify effect of local emissions } \\
\text { on existing and future chloride- } \\
\text { based estimates of recharge }\end{array}$ \\
\hline Upland area recharge & $\begin{array}{l}\text { Recharge at upper elevations can } \\
\text { affect groundwater movement but } \\
\text { is not well known }\end{array}$ & $\begin{array}{l}\text { Identify methods to characterize } \\
\text { recharge rates across upper } \\
\text { elevations }\end{array}$ \\
\hline Lysimetry & $\begin{array}{l}\text { Representativeness of lysimeters is } \\
\text { limited when soil water dynamics, } \\
\text { temperature, airflow, and boundary } \\
\text { conditions are altered significantly } \\
\text { compared to an undisturbed and } \\
\text { unrestricted soil column }\end{array}$ & $\begin{array}{l}\text { Examine the issues using a } \\
\text { numerical model and identify those } \\
\text { that are important to recharge } \\
\text { estimation }\end{array}$ \\
\hline $\begin{array}{l}\text { Spatial extrapolation of recharge } \\
\text { dependence on hydraulic property } \\
\text { data }\end{array}$ & $\begin{array}{l}\text { Fayer and Walters (1995) } \\
\text { constructed recharge map using } \\
\text { simulations for nearly } 60 \% \text { of the } \\
\text { Hanford Site; those simulations } \\
\text { relied on hydraulic properties } \\
\text { derived from small number of cores } \\
\text { and repacked samples }\end{array}$ & $\begin{array}{l}\text { Use latest hydraulic property } \\
\text { database to re-simulate the } \\
\text { conditions simulated for the } \\
\text { recharge map and include soil } \\
\text { variability estimates in additional } \\
\text { simulations }\end{array}$ \\
\hline Temperature effects & $\begin{array}{l}\text { High subsurface temperatures (e.g., } \\
\text { around tank farms) can affect } \\
\text { recharge rates }\end{array}$ & $\begin{array}{l}\text { Conduct modeling test to estimate } \\
\text { impact of tanks on recharge }\end{array}$ \\
\hline $\begin{array}{l}\text { Anomalous groundwater mound } \\
\text { north of Gable Mountain }\end{array}$ & $\begin{array}{l}\text { Unusual and persistent groundwater } \\
\text { mound on the north side of Gable } \\
\text { Mountain is perplexing }\end{array}$ & $\begin{array}{l}\text { Characterize recharge on the north } \\
\text { side of Gable Mountain }\end{array}$ \\
\hline
\end{tabular}


Table 5.2. Recommendations for Field Lysimeter Test Facility Lysimeters

\begin{tabular}{|c|c|c|c|c|c|c|c|c|}
\hline \multirow[b]{2}{*}{ Test Description } & \multicolumn{3}{|c|}{ Precipitation } & \multicolumn{3}{|c|}{ Vegetation } & \multirow{2}{*}{$\begin{array}{l}\text { Lysimeter } \\
\text { ID }\end{array}$} & \multirow[b]{2}{*}{ Recommendation } \\
\hline & $1 \mathrm{x}$ & $2 / 3 x$ & $3 x$ & NV & SRV & DRV & & \\
\hline \multirow[t]{5}{*}{ Hanford Barrier } & $\mathrm{X}$ & & & & & $\mathrm{X}$ & W1 & Continue \\
\hline & $\mathrm{X}$ & & & & & $X^{g}$ & $\mathrm{C} 3$ & Continue \\
\hline & $\mathrm{X}$ & & & $\mathrm{X}$ & & & D1 & Continue \\
\hline & & $\mathrm{X}$ & & & & $\mathrm{X}$ & W3 & Continue \\
\hline & & $\mathrm{X}$ & & & & $\mathrm{X}$ & C6 & Continue \\
\hline \multirow{2}{*}{$\begin{array}{l}\text { Eroded Prototype } \\
\text { Barrier }\end{array}$} & $\mathrm{X}$ & & & & & $\mathrm{X}$ & D3 & Continue \\
\hline & & & $\mathrm{X}$ & & & $\mathrm{X}$ & D13 & Continue \\
\hline \multirow[t]{2}{*}{ Gravel Mulch } & $\mathrm{X}$ & & & $\mathrm{X}$ & & & $\mathrm{C} 1$ & $\begin{array}{l}\text { Continue after blending dune sand into } \\
\text { gravel mulch }\end{array}$ \\
\hline & & $\mathrm{X}$ & & $\mathrm{X}$ & & & $\mathrm{C} 4$ & $\begin{array}{l}\text { Continue after blending dune sand into } \\
\text { gravel mulch }\end{array}$ \\
\hline \multirow[t]{2}{*}{ Pit-Run Sand } & $\mathrm{X}$ & & & & & $X^{g}$ & $\mathrm{C} 2$ & Continue \\
\hline & & $\mathrm{X}$ & & & & $\mathrm{X}$ & $\mathrm{C} 5$ & Continue \\
\hline Basalt Side Slope & $\mathrm{X}$ & & & $\mathrm{X}$ & & & D2 & Discontinue and make available \\
\hline $\begin{array}{l}\text { Sandy Gravel } \\
\text { Side Slope }\end{array}$ & $\mathrm{X}$ & & & $X$ & & & D4 & $\begin{array}{l}\text { Continue after blending dune sand into } \\
\text { surface }\end{array}$ \\
\hline \multirow{4}{*}{$\begin{array}{l}\text { Hanford Barrier } \\
\text { Erosion/Dune } \\
\text { Sand Deposition }\end{array}$} & $\mathrm{X}$ & & & & $\mathrm{X}$ & & D5 & Continue \\
\hline & $\mathrm{X}$ & & & & $\mathrm{X}$ & & W2 & Continue \\
\hline & & & $\mathrm{X}$ & & $\mathrm{X}$ & & D12 & Continue \\
\hline & & & $X$ & & $X$ & & W4 & Continue \\
\hline \multirow{2}{*}{$\begin{array}{l}\text { Sand Dune } \\
\text { Migration }\end{array}$} & $\mathrm{X}$ & & & & $X$ & & D6 & Continue \\
\hline & & & $\mathrm{X}$ & & $\mathrm{X}$ & & D8 & Continue \\
\hline \multirow{2}{*}{$\begin{array}{l}\text { Modified RCRA } \\
\text { Subtitle C Barrier }\end{array}$} & $\mathrm{X}$ & & & & & $\mathrm{X}$ & D7 & Continue \\
\hline & & & $\mathrm{X}$ & & & $\mathrm{X}$ & D9 & Continue \\
\hline \multirow[t]{3}{*}{ Not in use } & & & & & & & D10 & Available \\
\hline & & & & & & & D11 & Available \\
\hline & & & & & & & D14 & Available \\
\hline
\end{tabular}

Vegetation symbols: $\mathrm{NV}=$ no vegetation, $\mathrm{SRV}=$ shallow rooted vegetation, and $\mathrm{DRV}=$ deep rooted vegetation.

Superscripts: "g" = sagebrush planted but died, leaving only grasses.

\subsubsection{Integrated Disposal Facility Dune Site}

We recommend that monitoring of this site continue. The IDF Dune Site is the only natural area on the 200 Area Central Plateau instrumented to monitor water balance and estimate recharge. The site should be monitored intensively if the recharge conditions warrant (e.g., low air temperatures and higher than normal precipitation in winter; extraordinarily high spring or summer precipitation events); otherwise, the monitoring effort should be minimal. 
We recommend that several of the current monitoring locations be instrumented using the same water content and matric potential sensors deployed in tank farms (interim covers) and BC Cribs (desiccation). These sensors would provide model comparison information, real-time automated measurements, an opportunity to cross-calibrate with the neutron probe, and the ability to compare estimates of recharge flux based on the sensor data with estimates derived from the neutron probe data.

\subsubsection{Solid Waste Landfill Lysimeter}

We recommend that monitoring of the SWL Lysimeter continue until such time as a remediation decision (e.g., a cover) is implemented. The measurement area of the SWL Lysimeter is the largest at the Hanford Site and the lysimeter is deep enough to be unaffected by vegetation. We also recommend that the water flux meters be removed prior to the SWL being remediated.

\subsection{4 $\quad 300$ North Lysimeter}

We recommend that monitoring of the 300 North Lysimeter continue. As the oldest lysimeter in operation (since 1978), the 300 North Lysimeter provides a long-term record for coarse unvegetated sand.

\subsubsection{Grass Site}

We recommend that the monitoring at the Grass Site be continued as long as the WFMs are functioning. As one of the oldest field sites (since 1983), the Grass Site provides data on water balance in a naturally layered system. If the WFMs cease to function, we recommend the site be closed and resources targeted on natural sites much closer to the 200 Area Central Plateau.

\subsection{Modeling Calibration and Validation}

The data collected at the FLTF ought to be used for model calibration and validation tests. The results of such tests can be used to strengthen the technical basis of simulation studies of future scenarios. 



\subsection{References}

Bacon DH and BP McGrail. 2002. Effect of Design Change on Remote-Handled Trench Waste Form Release Calculations. PNNL-13947, Pacific Northwest National Laboratory, Richland, Washington.

DePaolo DJ, ME Conrad, K Maher, and GW Gee. 2004. "Evaporation Effects on Oxygen and Hydrogen Isotopes in Deep Vadose Zone Pore Fluids at Hanford, Washington." Vadose Zone Journal 3:220-232.

Fayer MJ. 2000. UNSAT-H Version 3.0: Unsaturated Soil Water and Heat Flow Model: Theory, User Manual, and Examples. PNNL-13249, Pacific Northwest National Laboratory, Richland, Washington.

Fayer MJ and GW Gee. 2006. "Multiple-Year Water Balance of Soil Covers in a Semiarid Setting." Journal of Environmental Quality 35:366-377.

Fayer MJ and JM Keller. 2007. Recharge Data Package for Hanford Single-Shell Tank Waste Management Areas. PNNL-16688, Pacific Northwest National Laboratory, Richland, Washington.

Fayer MJ and JE Szecsody. 2004. Recharge Data Package for the 2005 Integrated Disposal Facility Performance Assessment. PNNL-14744, Pacific Northwest National Laboratory, Richland, Washington.

Fayer MJ and TB Walters. 1995. Estimated Recharge Rates at the Hanford Site. PNL-10285, Pacific Northwest Laboratory, Richland, Washington.

Fayer MJ, FO Khan, EM Murphy, CW Lindenmeier, JL Downs, and BN Bjornstad. 1999. Recharge Data Package for the Immobilized Low-Activity Waste 2001 Performance Assessment. PNNL-13033, Pacific Northwest National Laboratory, Richland, Washington.

Freeman HD and GW Gee. 1989. Hanford Protective Barriers Program Asphalt Barrier StudiesFY 1988. PNL-6874, Pacific Northwest Laboratory, Richland, Washington.

Gee GW and TL Jones. 1985. Lysimeters at the Hanford Site. Present Use and Future Needs. PNL-5578, Pacific Northwest Laboratory, Richland, Washington.

Gee GW, RR Kirkham, JL Downs, and MD Campbell. 1989. The Field Lysimeter Test Facility (FLTF) at the Hanford Site: Installation and Initial Tests. PNL-6810, Pacific Northwest Laboratory, Richland, Washington.

Gee GW, MJ Fayer, ML Rockhold, and MD Campbell. 1992. "Variations in Recharge at the Hanford Site." Northwest Science 66:237-250.

Gee GW, DG Felmy, JC Ritter, MD Campbell, JL Downs, MJ Fayer, RR Kirkham, and SO Link. 1993. Field Lysimeter Test Facility Status Report IV: FY 1993. PNL-8911, Pacific Northwest Laboratory, Richland, Washington.

Gee GW, AL Ward, LL Cadwell, and JC Ritter. 2002. "A Vadose Zone Water Fluxmeter with Divergence Control.” Water Resources Research 38(8):1141-1147. 
Gee GW, ZF Zhang, and AL Ward. 2003. “A Modified Vadose Zone Fluxmeter with Solution Collection Capability." Vadose Zone Journal 2:627-632.

Hoitink DJ, KW Burk, JV Ramsdell, Jr., and WJ Shaw. 2005. Hanford Site Climatological Summary 2004 with Historical Data. PNNL-15160, Pacific Northwest National Laboratory, Richland, Washington.

Hsieh JJC, LE Brownell, and AE Reisenauer. 1973. Lysimeter Experiment Description and Progress Report on Neutron Measurements. BNWL-1711, Battelle Pacific Northwest Laboratories, Richland, Washington.

Murphy EM, JE Szecsody, and SJ Phillips. 1991. A Study Plan for Determining Recharge Rates at the Hanford Site Using Environmental Tracers. PNL-7626, Pacific Northwest Laboratory, Richland, Washington.

Nichols WE, ML Rockhold, and JL Downs. 2008. Compendium of Data for the Hanford Site (Fiscal Years 2004 to 2008) Applicable to Estimation of Recharge Rates. PNNL-17841, Pacific Northwest National Laboratory, Richland, Washington.

Phillips FM. 1994. "Environmental Tracers for Water Movement in Desert Soils of the American Southwest." Soil Science Society of America Journal 58(1):15-24.

Rickard WH and BE Vaughn (eds.). 1988. Chapter 6: "Plant Communities: Characteristics and Responses." In Shrub-Steppe, Balance and Change in a Semi-Arid Terrestrial Ecosystem. Elsevier, New York.

Rockhold ML, DL Saunders, CE Strickland, SR Waichler, and RE Clayton. 2009. Soil Water Balance and Recharge Monitoring at the Hanford Site - FY09 Status Report. PNNL-18807, Pacific Northwest National Laboratory, Richland, Washington.

Scanlon BR. 2000. "Uncertainties in Estimating Water Fluxes and Residence Times using Environmental Tracers in an Arid Unsaturated Zone.” Water Resources Research 36(2):395-409.

Scanlon BR, RW Healy, and PG Cook. 2002. "Choosing Appropriate Techniques for Quantifying Groundwater Recharge.” Hydrogeology Journal 10:18-39.

Sheppard SC, WG Evenden, and CR Macdonald. 1998. "Variation Among Chlorine Concentration Ratios for Native and Agronomic Plants.” Journal of Environmental Radiation (43):65-76.

Singleton MJ, K Maher, DJ DePaoloa, ME Conrad, and PE Dresel. 2006. "Dissolution Rates and Vadose Zone Drainage from Strontium Isotope Measurements of Groundwater in the Pasco Basin, Washington Unconfined Aquifer." Journal of Hydrology 321:39-58.

Thomas GW and AR Swoboda. 1970. "Anion Exclusion Effects on Chloride Movement in Soils." Soil Science 110(3):163-166.

Tyler SW, BR Scanlon, GW Gee, and GB Allison (eds.). 1999. "Water and Solute Transport in Arid Vadose Zones." In Vadose Zone Hydrology, Oxford University Press, New York. 
Ward AL. 2007. Geotechnical, Hydrogeologic and Vegetation Data Package for 200-UW-1 Waste Site Engineered Surface Barrier Design. PNNL-17134, Pacific Northwest National Laboratory, Richland, Washington.

Ward AL, GW Gee, and SO Link. 1997. Hanford Prototype-Barrier Status Report: FY 1997. PNNL-11789, Pacific Northwest National Laboratory, Richland, Washington.

Ward AL, MD White, EJ Freeman Jr., and ZF Zhang. 2005. STOMP Sparse Vegetation Evapotranspiration Model for the Water-Air-Energy Operational Mode. PNNL-15465, Pacific Northwest National Laboratory, Richland, Washington.

Ward AL, SO Link, CE Strickland, KE Draper, and RE Clayton. 2007. 200-BP-1 Prototype Hanford Barrier Annual Monitoring Report for Fiscal Years 2005 Through 2007. PNNL-17176, Pacific Northwest National Laboratory, Richland, Washington.

White MD and M Oostrom. 2006. STOMP Subsurface Transport Over Multiple Phases, Version 4.0, User's Guide. PNNL-15782, Pacific Northwest National Laboratory, Richland, Washington.

Wittreich CD and CR Wilson. 1991. "Use of Lysimeters to Monitor a Sanitary Landfill." In Proceedings of the Conference on Lysimeters for Evapotranspiration and Environmental Measurements, Honolulu, Hawaii, July 23-25, 1991, pp. 397-405. Irrigation Division, American Society of Civil Engineers, Reston, Virginia. 



\section{Distribution}

No. of

Copies

ONSITE

2 DOE Richland Operations Office

KD Leary

JG Morse

4 CH2M HILL Plateau Remediation Company

MW Benecke

WJ Mcmahon

SW Petersen

CD Wittreich
No. of

\section{Copies}

7 Pacific Northwest National Laboratory

MJ Fayer

K9-33

D Felmy

K6-75

MD Freshley

K9-33

RS Herrington

K2-21

ML Rockhold

K9-36

DL Saunders

K2-21

AL Ward

K9-33
R3-60

H8-51

R3-50

H8-15

Distr.1 




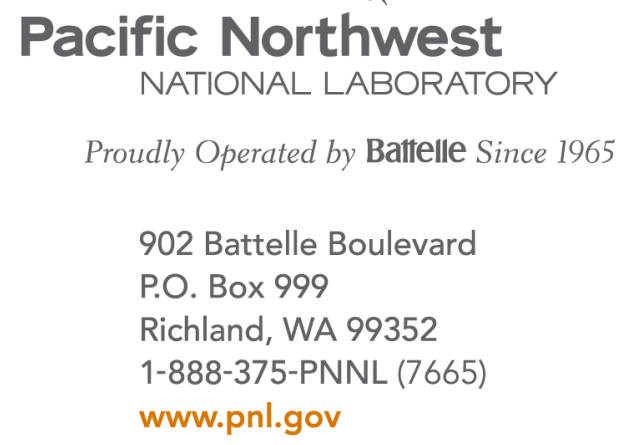

Pacific Northwest

NATIONAL LABORATORY

Proudly Operated by Battelle Since 1965

902 Battelle Boulevard

P.O. Box 999

Richland, WA 99352

1-888-375-PNNL (7665)

www.pnl.gov 